Article

\title{
Seven Decades of Coastal Change at Barter Island, Alaska: Exploring the Importance of Waves and Temperature on Erosion of Coastal Permafrost Bluffs
}

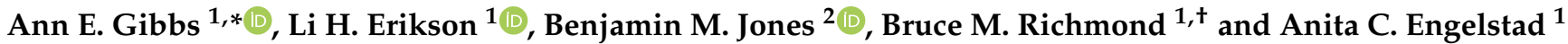 \\ 1 U.S. Geological Survey, Pacific Coastal and Marine Science Center, Santa Cruz, CA 95060, USA; \\ lerikson@usgs.gov (L.H.E.); aengelstad@usgs.gov (A.C.E.) \\ 2 Institute of Northern Engineering, University of Alaska Fairbanks, Fairbanks, AK 99775, USA; \\ bmjones3@alaska.edu \\ * Correspondence: agibbs@usgs.gov \\ + Deceased.
}

check for updates

Citation: Gibbs, A.E.; Erikson, L.H.; Jones, B.M.; Richmond, B.M.; Engelstad, A.C. Seven Decades of Coastal Change at Barter Island, Alaska: Exploring the Importance of Waves and Temperature on Erosion of Coastal Permafrost Bluffs. Remote Sens. 2021, 13, 4420. https:// doi.org/10.3390/rs13214420

Academic Editor: Michael Lim

Received: 16 September 2021

Accepted: 31 October 2021

Published: 3 November 2021

Publisher's Note: MDPI stays neutral with regard to jurisdictional claims in published maps and institutional affiliations.

Copyright: (c) 2021 by the authors. Licensee MDPI, Basel, Switzerland. This article is an open access article distributed under the terms and conditions of the Creative Commons Attribution (CC BY) license (https:// creativecommons.org/licenses/by/ $4.0 /)$.

\begin{abstract}
Observational data of coastal change over much of the Arctic are limited largely due to its immensity, remoteness, harsh environment, and restricted periods of sunlight and ice-free conditions. Barter Island, Alaska, is one of the few locations where an extensive, observational dataset exists, which enables a detailed assessment of the trends and patterns of coastal change over decadal to annual time scales. Coastal bluff and shoreline positions were delineated from maps, aerial photographs, and satellite imagery acquired between 1947 and 2020, and at a nearly annual rate since 2004. Rates and patterns of shoreline and bluff change varied widely over the observational period. Shorelines showed a consistent trend of southerly erosion and westerly extension of the western termini of Barter Island and Bernard Spit, which has accelerated since at least 2000. The $3.2 \mathrm{~km}$ long stretch of ocean-exposed coastal permafrost bluffs retreated on average $114 \mathrm{~m}$ and at a maximum of $163 \mathrm{~m}$ at an average long-term rate (70 year) of $1.6 \pm 0.1 \mathrm{~m} / \mathrm{yr}$. The long-term retreat rate was punctuated by individual years with retreat rates up to four times higher (6.6 $\pm 1.9 \mathrm{~m} / \mathrm{yr}$; 2012-2013) and both long-term (multidecadal) and short-term (annual to semiannual) rates showed a steady increase in retreat rates through time, with consistently high rates since 2015. A best-fit polynomial trend indicated acceleration in retreat rates that was independent of the large spatial and temporal variations observed on an annual basis. Rates and patterns of bluff retreat were correlated to incident wave energy and air and water temperatures. Wave energy was found to be the dominant driver of bluff retreat, followed by sea surface temperatures and warming air temperatures that are considered proxies for evaluating thermo-erosion and denudation. Normalized anomalies of cumulative wave energy, duration of open water, and air and sea temperature showed at least three distinct phases since 1979: a negative phase prior to 1987, a mixed phase between 1987 and the early to late 2000s, followed by a positive phase extending to 2020. The duration of the open-water season has tripled since 1979, increasing from approximately 40 to 140 days. Acceleration in retreat rates at Barter Island may be related to increases in both thermodenudation, associated with increasing air temperature, and the number of niche-forming and block-collapsing episodes associated with higher air and water temperature, more frequent storms, and longer ice-free conditions in the Beaufort Sea.
\end{abstract}

Keywords: permafrost bluff retreat; shoreline change; coastal dynamics; Arctic; ANWR; ERA5 reanalysis

\section{Introduction}

Processes driving coastal change in permafrost environments can be fundamentally reduced to mechanical and thermal processes [1,2], and shorelines anchored by permafrostrich substrates and those influenced by the presence of sea ice, are highly vulnerable to the effects of climate change. Observed and projected increases in the duration of the ice-free season, warming of land, air, and ocean temperatures, changes in wave intensity 
and direction and water levels in the Alaskan coastal region over the past several decades (e.g., [3-7]) will likely drive a related response in permafrost coastline behavior because of the linked mechanisms of shoreline change [8]. Attributing this response in coastal behavior is problematic, however, largely because observational data are limited due to the Arctic's remoteness, harsh environment, poor geodetic infrastructure, and restricted windows of opportunity for observation (limited daylight and ice-free conditions).

At only a handful of sites across the Arctic are historical datasets available over a period of time long enough to identify a significant change in trend, particularly prior to the late 1970s when remotely sensed satellite data became widely available (see for example [8]). Along the north Alaskan Beaufort and Chukchi Sea coasts, for example, regional shoreline data exist for only four time periods: 1940s, 1980s, 2000s, and 2010s. Shoreline change rates calculated using these data indicate the coast has dominantly erosional over the past seven decades; however, no clear statistically significant change in trend through time was identified based on the decadal-scale time periods [9].

Long-term multiyear analysis of shoreline position provides important information on overall trends and patterns and can be compared with rates of change from other locations; however, details on timing and processes and an understanding of the interplay between the two in the overall pattern of change requires detailed observation and measurements acquired at appropriate time scales. This type of analysis allows us to test questions related to whether erosion is gradual or episodic, and under what circumstances. Are erosion rates accelerating, and what are the significant processes driving the change? The ability to quantify coastal change and understand these patterns and drivers at appropriate time scales is important for modeling and projecting future coastal behavior, especially as Arctic air and water temperatures increase and stronger and more frequent storms can impact the coast later in the season as seasonal sea ice forms later and melts earlier.

Barter Island, Alaska, is one of the few locations in the Arctic where a relative abundance of historical imagery exists, for 21 individual years between 1947 and 2020, including very-high resolution satellite and aerial photography on a near annual basis for the last two decades. Here, we utilize this relatively unique dataset to document 73 years of the morphological evolution of Barter Island and its neighboring barrier island, Bernard Spit, and quantify decadal to interannual rates and patterns of change for a $3.2 \mathrm{~km}$ long stretch of Barter Islands coastal permafrost bluffs. Finally, we explore the relationship between observed and hindcast (1979-2019) air and water temperature, wave energy, and incident wave direction on the observed change.

\section{Study Area}

Barter Island is located on the Alaskan Beaufort Sea coast, approximately $120 \mathrm{~km}$ west of the United States-Canadian border and along the northern boundary of the U.S. Arctic National Wildlife Refuge (ANWR; Figure 1). The island has a long history of Inupiat occupation and was a major trade center until the late 19th century [10]. Development and infrastructure on the island are limited to the City and Native Village Kaktovik (2019 population 235, [10]) and U.S. Department of Defense Long Range Radar Station (LRRS). The radar station, originally constructed in the 1950s by the U.S. Air Force as one of the Distant Early Warning (DEW) Line sites, continues to operate today as part of the North Warning System (NWS). Similar to many communities in northern Alaska, subsistence hunting, fishing, and whaling play a major role in the local economy and lifestyle on Barter Island. Access to the island is limited to boats, barges, and aircraft. No permanent roads lead to the island. 

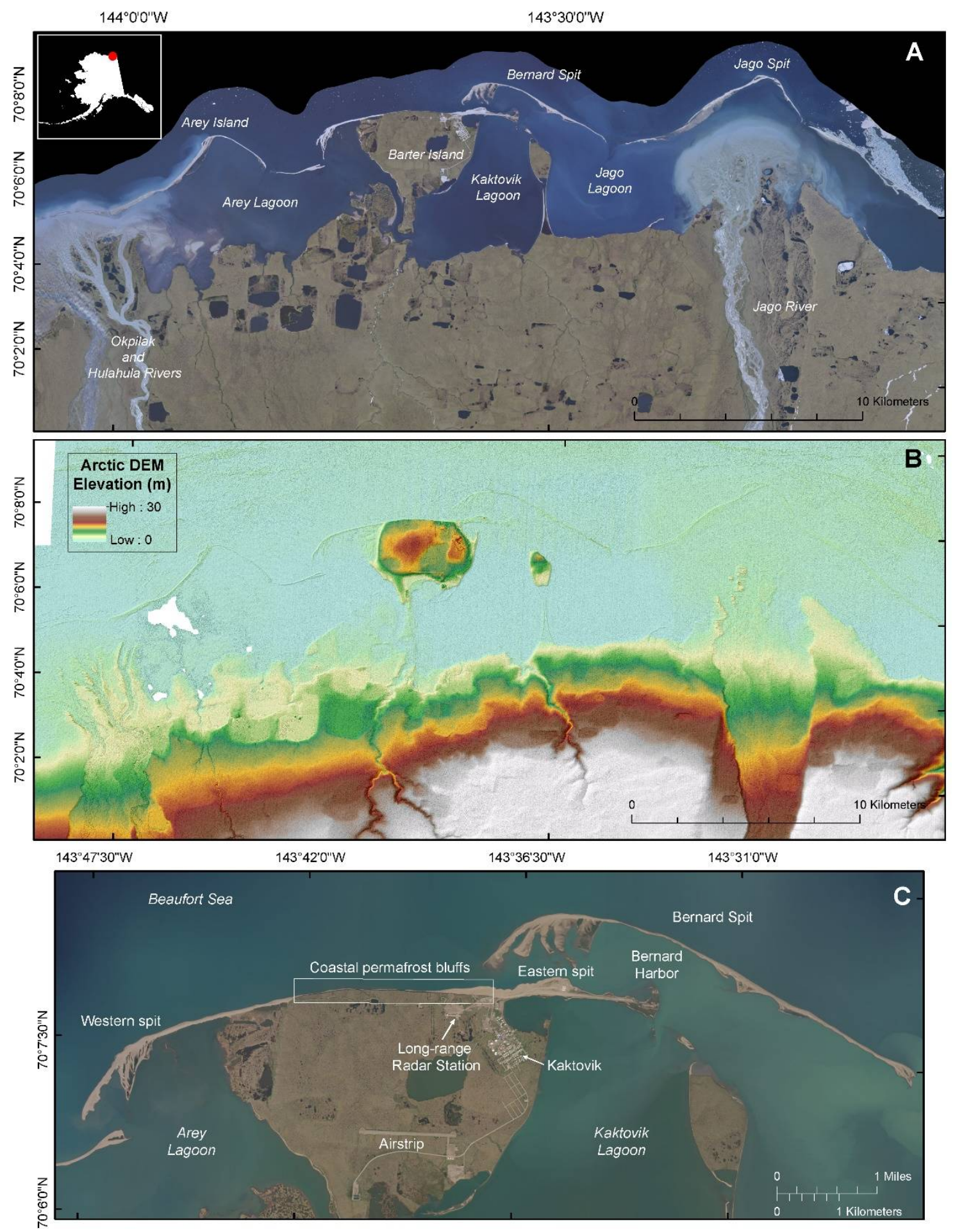

Figure 1. (A) Regional location of the area near Barter Island, Alaska, showing locations discussed in the text. Imagery base is 2013 SPOT5 RGB (https:/ / gis.data.alaska.gov/pages /Imagery\%20Program; accessed on 1 October 2021). (B) Elevation map of the region from the Arctic DEM (https:/ / www.pgc.umn.edu/data/arcticdem/ accessed on 3 March 2021). Note the anomalously high elevation of Barter Island compared to the surrounding coastal features. (C) Detailed location map of Barter Island and Bernard Spit. The white box outlines the $3.2 \mathrm{~km}$ section of coastal bluffs. Imagery base is Alaska High Resolution Imagery RGB (https:/ / gis.data.alaska.gov/pages/Imagery\%20Program; accessed on 1 October 2021).

Barter Island is a remnant tundra island that sits between two large deltas of the Jago and Okpilak-Hulahula Rivers. It is one of the largest islands along Alaska's coast, with a to- 
tal area of nearly 1600 hectares (six square miles). The geological history of the island is not well known, but surficial coastal plain sediments in the area are thought to be composed of reworked eolian, alluvial, fluvial, and marine deposits of the Quaternary Gubik Formation, covered by a 2-3 m thick layer of late Pleistocene and Holocene peaty/muddy thaw-lake sediment [11-13]. Barter Island is anomalously high compared to the surrounding coastal features, reaching up to $16 \mathrm{~m}$ high in the central part of the island (Figure 1B). Broad low-lying ( $<2 \mathrm{~m}$ high) sand and gravel spits extend east and west from the topographically higher tundra hinterland (Figure 1C). The community of Kaktovik and adjacent U.S. Air Force radar site sit on the north shore of the island near the eastern end of a nearly $3 \mathrm{~km}$ stretch of eroding coastal permafrost bluffs. The bluffs range in height from a few meters to more than ten meters high and consist of a complex sequence of poorly consolidated material ranging from dense clay, interbedded and massive sand and gravel, massive ice, which has been interpreted as buried glacial ice [14-16], wedge ice, segregated ice layers, massive ice, and thermokarst cave ice, all capped with a surface peat layer $[13,16,17]$. Barter Island, like the entire North Slope of Alaska, is in a zone of continuous permafrost, with a shallow active layer (historically generally less than $1 \mathrm{~m}$ deep) that is subject to thawing during the summer season. Narrow ( $<20 \mathrm{~m}$ wide) beaches front most of the coastal bluffs. Bernard Spit, a low-lying barrier island to the northeast, protects much of Barter Island's eastern spit from incident wave energy. The island is subject to overwash and breaching during periods of high waves and elevated water level. There is an apparent absence of ice-bonded permafrost in Kaktovik Lagoon [18].

The Beaufort Sea is typically covered with sea ice from approximately October through June. Prevailing winds are easterly and average near $5.8 \mathrm{~m} / \mathrm{s}$ with little annual variation $[19,20])$. The region is microtidal with a mean diurnal range of $18 \mathrm{~cm}[21]$; however, water levels can become elevated or depressed up to several meters due to winds and low-pressure systems; westerly winds tend to elevate water levels, whereas easterly winds tend to lower water levels $[4,22,23]$. Wave directions are predominantly from the east, but the largest waves are associated with the passage of large low-pressure systems that generally approach from the west. Studies of projected climate patterns indicate a poleward shift in storm tracks [24] and particularly along the Barter Island coast [4]. The near E-W trending Barter Island shoreline coincides with a nearly balanced E-W longshore transport regime that drives sediment redistribution along the open coast. This is reflected by the large sand spits that extend both east and west of the island.

Coastal geomorphic processes are, for the most part, limited to three ice-free months of the year between late July and the onset of shorefast ice in October. Starting in late July to mid-August, low-pressure cells originating in the Pacific Ocean or Chukchi Sea traverse eastward across Alaska and the Beaufort Sea bringing with them high winds that can generate storm surges possibly as high as $3 \mathrm{~m}$ and waves as high as $6 \mathrm{~m}$ [4,12,25-27]. The magnitude of littoral transport on the beaches and barrier islands in this area is thought to be low along this coast compared to lower latitude coasts due to relatively low wave energy and short open water season [12]. Sediment transport directions are bimodal with dominant easterly waves generating limited longshore sediment transport from east to west and infrequent but larger westerly waves generating longshore sediment transport from west to east.

Similar to permafrost bluffs elsewhere in the Arctic, primary bluff failure modes are a combination of thermal denudation on the bluff face throughout the summer and thermomechanical removal of debris material fronting the bluffs and niching of the base associated with waves and high-water levels (wind or storm surge) followed by rotational slumping and block collapse [1,2,28-31]. Ground ice typically occupies 60-90\% of the volume of near-surface deposits [16,32], and it is a major factor contributing to the high coastal erosion rates [33]. Retreat rates appear to be largely dependent on ice content, the frequency and intensity of storms, runup elevation, and seawater and air temperatures [34-36]. The pattern of change is predominantly landward retreat of the top of the bluffs, removal of 
the debris apron and subsequent niching at the base of the bluffs, followed by continued erosion of the bluff face and deposition of debris at the base of the bluff [29].

\section{Methods}

Methodologies used to quantify rates and patterns of landscape change and three potential physical drivers of change are outlined in Figure 2. Shoreline and bluff edge positions were delineated from a combination of historical maps, aerial photography, declassified satellite photography, and very-high resolution satellite imagery spanning a 73 year period between 1947 and 2020. Spatial resolution of the datasets ranges from 0.08 to $4.1 \mathrm{~m}$ (Table 1). Shoreline data comprise 21 individual years spanning 1947 to 2020; however, there are only 6 years with complete shoreline coverage over the study area. Bluff edge data comprise 22 individual years ranging from 1950 to 2020. A useable bluff edge position could not be determined from the 1947 nor 1987 T-sheet data. Images were georeferenced and rectified using map coordinates, ground survey points, and/or image-to-image correlation of photo-identifiable ground features. A total root mean square rectification error was determined for each image based on the residuals. The top edge of the bluff and the instantaneous land-water shoreline were manually digitized in a GIS, and a total position uncertainty of the feature was determined as the quadrature sum of all uncertainties, including image resolution, georeferencing/rectification, and feature digitization [9] (Table 1).

Table 1. Datasets used for bluff and shoreline change analysis.

\begin{tabular}{|c|c|c|c|c|c|c|}
\hline Year & Date & Source & Image Type & Resolution (m) & RMSE & Features \\
\hline 1947 & 07-01-1947 & NOAA & 1:20,000 scale T-sheet & 4.10 & - & Shoreline \\
\hline 1950 & 08-02-1950 & Earth Explorer & $\begin{array}{c}\text { Panchromatic aerial } \\
\text { photography }\end{array}$ & 0.53 to 0.56 & 0.54 to 0.92 & $\begin{array}{l}\text { Shoreline and } \\
\text { bluff }\end{array}$ \\
\hline 1955 & 07-24-1955 & Earth Explorer & $\begin{array}{c}\text { Panchromatic aerial } \\
\text { photography }\end{array}$ & 1.49 & 1.30 & $\begin{array}{l}\text { Shoreline and } \\
\text { bluff }\end{array}$ \\
\hline 1969 & 07-25-1969 & Earth Explorer & $\begin{array}{c}\text { Panchromatic CORONA } \\
\text { satellite } \\
\text { photography }\end{array}$ & 3.94 & 1.36 & $\begin{array}{l}\text { Shoreline and } \\
\text { bluff }\end{array}$ \\
\hline 1975 & 07-07-1975 & Earth Explorer & $\begin{array}{l}\text { Panchromatic Hexagon satellite } \\
\text { photography }\end{array}$ & 1.07 & 2.63 & $\begin{array}{l}\text { Shoreline and } \\
\text { bluff }\end{array}$ \\
\hline 1979 & 07-13-1979 & Earth Explorer & $\begin{array}{l}\text { Color-infrared aerial } \\
\text { photography (AHAP) }\end{array}$ & 1.00 & 2.00 & $\begin{array}{l}\text { Shoreline and } \\
\text { bluff }\end{array}$ \\
\hline 1987 & 08-01-1987 & NOAA & 1:50,000 T-sheet & 3.80 & - & Shoreline only \\
\hline 2000 & 09-19-2000 & Maxar & $\begin{array}{l}\text { Panchromatic satellite imagery } \\
\text { (IKONOS) }\end{array}$ & 1.01 & 1.30 & $\begin{array}{l}\text { Shoreline and } \\
\text { bluff }\end{array}$ \\
\hline 2004 & 09-18-2004 & Maxar & $\begin{array}{c}\text { Panchromatic satellite } \\
\text { imagery } \\
\text { (Quickbird) }\end{array}$ & 0.33 & 0.41 & $\begin{array}{l}\text { Shoreline and } \\
\text { bluff }\end{array}$ \\
\hline 2006 & 07-13-2006 & Maxar & $\begin{array}{l}\text { Panchromatic satellite imagery } \\
\text { (IKONOS) }\end{array}$ & 1.00 & 0.31 & Bluff only \\
\hline 2007 & 07-04-2007 & Maxar & $\begin{array}{c}\text { Panchromatic satellite imagery } \\
\text { (Quickbird) }\end{array}$ & 0.41 & 0.43 & $\begin{array}{l}\text { Shoreline and } \\
\text { bluff }\end{array}$ \\
\hline 2008 & 06-23-2008 & Maxar & $\begin{array}{c}\text { Panchromatic satellite imagery } \\
\text { (WV01) }\end{array}$ & 0.44 & 1.80 & Bluff only \\
\hline 2008 & 09-19-2008 & Maxar & $\begin{array}{c}\text { Panchromatic satellite imagery } \\
\text { (WV01) }\end{array}$ & 0.47 & 0.26 & $\begin{array}{l}\text { Shoreline and } \\
\text { bluff }\end{array}$ \\
\hline 2009 & 08-02-2009 & Maxar & $\begin{array}{l}\text { Panchromatic satellite imagery } \\
\text { (WV01) }\end{array}$ & 0.34 & 0.88 & $\begin{array}{l}\text { Shoreline and } \\
\text { bluff }\end{array}$ \\
\hline 2009 & 09-01-2009 & USGS & Lidar elevation model & 3.00 & - & Shoreline \\
\hline 2010 & $07-25-2010$ & Maxar & $\begin{array}{l}\text { Panchromatic satellite imagery } \\
\text { (WV02) }\end{array}$ & 0.32 & 0.69 & $\begin{array}{l}\text { Shoreline and } \\
\text { bluff }\end{array}$ \\
\hline 2010 & 09-06-2010 & Maxar & $\begin{array}{c}\text { Panchromatic satellite imagery } \\
\text { (WV02) }\end{array}$ & 0.32 & 0.85 & Bluff only \\
\hline
\end{tabular}


Table 1. Cont.

\begin{tabular}{|c|c|c|c|c|c|c|}
\hline Year & Date & Source & Image Type & Resolution (m) & RMSE & Features \\
\hline 2011 & 07-15-2011 & Maxar & $\begin{array}{l}\text { Panchromatic satellite imagery } \\
\text { (WV02) }\end{array}$ & 0.31 & 0.31 & $\begin{array}{l}\text { Shoreline and } \\
\text { bluff }\end{array}$ \\
\hline 2012 & 07-11-2012 & Maxar & $\begin{array}{c}\text { Panchromatic satellite imagery } \\
\text { (WV02) }\end{array}$ & 0.51 & 0.30 & $\begin{array}{l}\text { Shoreline and } \\
\text { bluff }\end{array}$ \\
\hline 2013 & 08-07-2013 & Maxar & $\begin{array}{l}\text { Panchromatic satellite imagery } \\
\text { (WV02) }\end{array}$ & 0.50 & 1.50 & Bluff only \\
\hline 2014 & 07-01-2014 & $\begin{array}{l}\text { Fairbanks } \\
\text { Fodar }\end{array}$ & $\begin{array}{c}\text { Natural color aerial } \\
\text { photography }\end{array}$ & 0.19 & - & $\begin{array}{l}\text { Shoreline and } \\
\text { bluff }\end{array}$ \\
\hline 2014 & 09-07-2014 & $\begin{array}{l}\text { Fairbanks } \\
\text { Fodar }\end{array}$ & $\begin{array}{l}\text { Natural color aerial } \\
\text { photography }\end{array}$ & 0.11 & - & $\begin{array}{l}\text { Shoreline and } \\
\text { bluff }\end{array}$ \\
\hline 2015 & 07-05-2015 & $\begin{array}{l}\text { Fairbanks } \\
\text { Fodar }\end{array}$ & $\begin{array}{c}\text { Natural color aerial } \\
\text { photography }\end{array}$ & 0.08 & - & $\begin{array}{l}\text { Shoreline and } \\
\text { bluff }\end{array}$ \\
\hline 2016 & 08-27-2016 & Maxar & $\begin{array}{c}\text { Panchromatic satellite imagery } \\
\text { (WV02) }\end{array}$ & 0.50 & 0.50 & $\begin{array}{l}\text { Shoreline and } \\
\text { bluff }\end{array}$ \\
\hline 2017 & 07-13-2017 & Maxar & $\begin{array}{c}\text { Pansharpened natural color } \\
\text { satellite } \\
\text { imagery (WV02) }\end{array}$ & 0.50 & 0.60 & $\begin{array}{l}\text { Shoreline and } \\
\text { bluff }\end{array}$ \\
\hline 2018 & $07-30-2018$ & Maxar & $\begin{array}{c}\text { Pansharpened natural color } \\
\text { satellite } \\
\text { imagery (WV02) }\end{array}$ & 0.50 & 0.50 & $\begin{array}{l}\text { Shoreline and } \\
\text { bluff }\end{array}$ \\
\hline 2019 & 09-05-2019 & Maxar & $\begin{array}{c}\text { Pansharpened mulitispectral } \\
\text { satellite } \\
\text { imagery (WV02) }\end{array}$ & 0.33 & 0.33 & $\begin{array}{l}\text { Shoreline and } \\
\text { bluff }\end{array}$ \\
\hline 2020 & $07-10-2020$ & Maxar & $\begin{array}{c}\text { Pansharpened natural color } \\
\text { satellite } \\
\text { imagery (WV02) }\end{array}$ & 0.50 & 0.50 & $\begin{array}{l}\text { Shoreline and } \\
\text { bluff }\end{array}$ \\
\hline
\end{tabular}

Bold text indicates shoreline datasets used in this analysis; grayed text indicates bluff and shoreline positions are included in [29] but not used in this analysis.

Change rates were calculated every $10 \mathrm{~m}$ alongshore using the Digital Shoreline Analysis System 5.0 [37] using either the linear regression or endpoint rate calculation methods, depending on the number of features selected for analysis (greater than 2 or equal to 2, respectively). Bluff change rates were calculated for 4 multidecadal time periods: 1950 to 2020, 1950 to 1975, 1975 to 2000, 2000 to 2020, and 21 semiannual to annual time periods (Table 2). Regionally averaged rate uncertainties were calculated using the reduced $n$ approach on long-term linear regression rates $[38,39]$ and the mean of the endpoint rate uncertainties (EPRunc) on individual transects as described in [37]. Shoreline change rates were calculated along the open coast from the east end of Bernard Spit to the west extent of Barter Island for the 6 years with data extending across the entire study area (1947, 1979, 2004, 2009, 2018, and 2020; Figure 1, Table 1). Additional details on methodology and uncertainty estimates can be found in $[9,37]$. Bluff edge and shoreline vectors, rate calculation data, and error and uncertainty statistics at individual transects are available at [40].

Attribution of bluff recession to three physical drivers was evaluated by computing cumulative wave power, ocean surface temperatures, and ambient air temperatures, and comparing these to bluff recession rates. Whereas process-based models are preferred for their granularity and better accuracy, here we employed wave power (propagated to the inshore region) and sea surface temperatures as indicators of thermoabrasion, and ambient air temperatures as proxies for thermodenudation.

Wave power $(W P)$ was computed with,

$$
W P=\frac{\rho g^{2}}{64 \pi} \cdot T_{e} \cdot H_{s}^{2}
$$


where $\rho$ is the density of water $\left(=1028 \mathrm{~kg} / \mathrm{m}^{3}\right), g$ is the gravitational acceleration $\left(=9.83 \mathrm{~m} / \mathrm{s}^{2}\right.$ at $\left.\mathrm{N} 70.1^{\circ}\right), H_{s}$ is the significant wave height (units of meters), and $T_{e}$ is the energy period (units of seconds), herein estimated with $0.538 \cdot T_{01}$, based on the JONSWAP wave spectrum [41].

Table 2. Barter Island bluff retreat rates.

\begin{tabular}{|c|c|c|c|c|c|c|c|}
\hline \multirow[b]{2}{*}{ Analysis Period } & \multirow[b]{2}{*}{ Total Years } & \multirow[b]{2}{*}{ \# of Years } & \multicolumn{3}{|c|}{ Bluff Retreat Rate (Meters/Year) } & \multirow[b]{2}{*}{ Mean Uncy } & \multirow[b]{2}{*}{ Reduced Uncy } \\
\hline & & & Mean & Maximum & Std. Dev. & & \\
\hline \multicolumn{8}{|c|}{ Decadal long-term rates } \\
\hline 1950-2020 & 70 & 25 & 1.6 & 2.2 & 0.4 & 0.1 & 0.1 \\
\hline 1950-1975 & 25 & 4 & 1.0 & 2.0 & 0.5 & 0.4 & 0.1 \\
\hline 1975-2000 & 25 & 3 & 1.5 & 2.5 & 0.5 & 0.2 & 0.2 \\
\hline $2000-2020$ & 19.8 & 20 & 2.7 & 5.2 & 1.4 & 0.3 & 0.1 \\
\hline \multicolumn{8}{|c|}{ Interannual short-term rates } \\
\hline 1950-1955 & 5.0 & 2 & 1.9 & 5.0 & 1.1 & 0.9 & 0.9 \\
\hline 1955-1969 & 14.0 & 2 & 1.0 & 2.4 & 0.8 & 0.4 & 0.4 \\
\hline 1969-1975 & 6.0 & 2 & 0.8 & 2.7 & 0.6 & 0.9 & 0.9 \\
\hline 1975-1979 & 4.0 & 2 & 0.7 & 4.0 & 0.7 & 1.1 & 1.1 \\
\hline 1979-2000 & 21.3 & 2 & 1.5 & 2.5 & 0.5 & 0.2 & 0.2 \\
\hline 2000-2004 & 4.0 & 2 & 1.8 & 4.9 & 0.8 & 0.8 & 0.8 \\
\hline 2004-2006 & 1.8 & 2 & 1.0 & 4.0 & 0.8 & 1.1 & 1.1 \\
\hline 2006-2007 & 1.0 & 2 & 1.2 & 5.5 & 1.2 & 2.3 & 2.3 \\
\hline 2007-2008 & 1.2 & 2 & 5.6 & 17.9 & 4.3 & 1.4 & 1.4 \\
\hline 2008-2009 & 0.9 & 2 & 2.5 & 8.0 & 1.7 & 1.7 & 1.7 \\
\hline 2009-2010 & 1.1 & 2 & 2.0 & 9.4 & 2.1 & 1.9 & 1.9 \\
\hline 2010-2011 & 0.9 & 2 & 0.9 & 13.3 & 1.7 & 2.3 & 2.3 \\
\hline 2011-2012 & 1.0 & 2 & 2.0 & 9.3 & 2.1 & 1.3 & 1.3 \\
\hline 2012-2013 & 1.1 & 2 & 6.6 & 21.3 & 5.2 & 1.9 & 1.9 \\
\hline 2013-2014 & 0.9 & 2 & 1.0 & 6.0 & 1.1 & 2.1 & 2.1 \\
\hline 2014-2015 & 1 & 2 & 1.6 & 7.0 & 1.4 & 0.4 & 0.4 \\
\hline 2015-2016 & 1.1 & 2 & 4.1 & 13.1 & 3.1 & 1.0 & 1.0 \\
\hline 2016-2017 & 0.9 & 2 & 2.9 & 18.2 & 3.9 & 1.7 & 1.7 \\
\hline 2017-2018 & 1.1 & 2 & 3.4 & 12.5 & 2.9 & 1.0 & 1.0 \\
\hline 2018-2019 & 1.0 & 2 & 4.1 & 17.4 & 3.9 & 0.5 & 0.5 \\
\hline 2019-2020 & 0.8 & 2 & 2.3 & 14.7 & 3.0 & 1.3 & 1.3 \\
\hline \multicolumn{8}{|c|}{2000 to 20204 year averaged rates } \\
\hline 2000-2004 & 4 & 2 & 1.8 & 4.9 & 0.8 & 0.8 & \\
\hline 2004-2008 & 4 & 4 & 2.4 & 6.4 & 1.4 & 2.5 & \\
\hline 2008-2012 & 4 & 4 & 3.0 & 6.8 & 1.7 & 0.4 & \\
\hline 2012-2016 & 4 & 4 & 3.4 & 8.5 & 2.4 & 0.4 & \\
\hline $2016-2020$ & 4 & 4 & 3.5 & 11.1 & 2.6 & 0.4 & \\
\hline
\end{tabular}

Akin to the concept of 'growing-degree-days' frequently used in agriculture, whereby differing threshold temperatures are used to determine accumulated heat units for different crops, we compute 'positive-degree-days' (PDD) as a possible indicator of thermodenudation. The PDD was computed as the cumulative sum of daily mean air temperatures above $0{ }^{\circ} \mathrm{C}$. Sea surface temperatures were similarly treated to compute PDSST. For evaluation of changes since 1979, WP, PDD, and PDSST were computed annually, whereas for evaluation with respect to bluff recession rates, WP was cumulated between subsequent timepoints of bluff position measurements, whilst PDD and PDSST were accumulated between the most recent of either the preceding measurement date or start of the year (i.e., thermal denudation was 'reset' to the current measurement date if multiple years passed between measurements).

All data used to estimate WP, PDD, PDSST, and duration of open water season were extracted from the ERA5 reanalysis (ERA5 I ECMWF). ERA5 is the 5th generation European 
Centre for Medium-Range Weather Forecasts (ECMWF) reanalysis of the global climate. It was developed by combining model data with vast observations from across the world into a globally complete and consistent dataset. The reanalysis dataset was created using a 4D-VAR sophisticated data assimilation method as part of the new ECMWF Integrated Forecasting System (IFS) CY41R2; it simulates hourly atmospheric fields at $0.25^{\circ}(\sim 30 \mathrm{~km})$ spatial resolution from 1979 onwards. The reanalysis additionally includes ocean wave parameters (at a $0.50^{\circ}(\sim 56 \mathrm{~km})$ resolution) derived from a fully coupled atmosphere-oceanwave model (ecWAM) that incorporates assimilation of satellite radar altimeter-derived wave height data from 1991 to present. Air and sea surface temperatures employed in this study were extracted from the grid cell closest to Barter Island. Wave parameters (heights, periods, and incident directions) were extracted from a grid cell approximately $30 \mathrm{~km}$ offshore in $\sim 20 \mathrm{~m}$ water depth. Because wave energy is a dominant driver of coastal erosion, and because ERA5, though relatively fine scale considering the global extent of the reanalysis product, is not able to resolve variations of wave energy within the inner nearshore region, the ERA5 wave time series was downscaled to the inner nearshore region using a local-scale wave model.

\section{Change rates:}

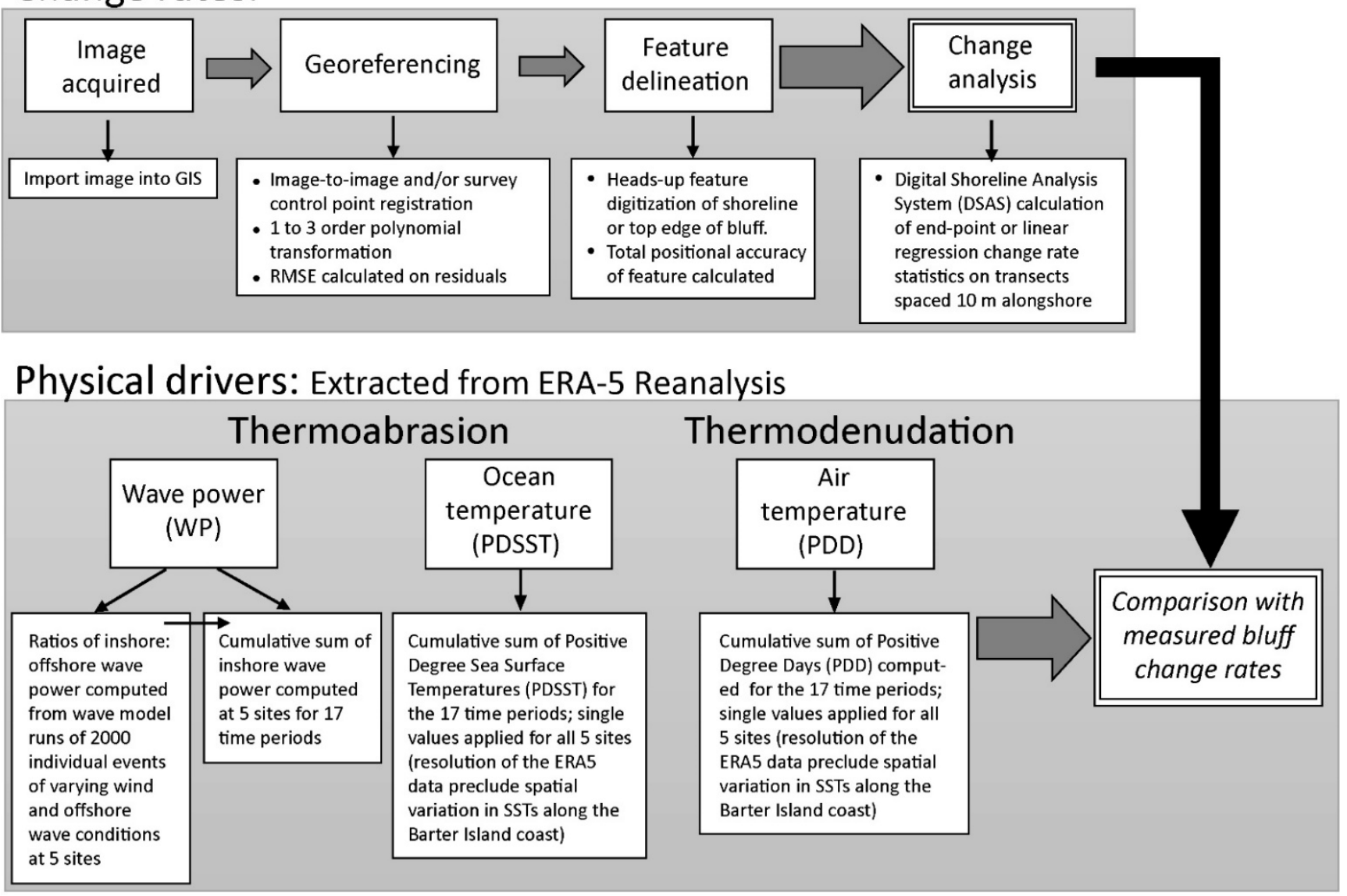

Figure 2. Flow chart outlining the study methodologies.

To propagate WP to the inner nearshore (here defined to be within the $5 \mathrm{~m}$ isobath and shoreline) a SWAN wave model consisting of a curvilinear grid with nominal resolution of $\sim 200 \mathrm{~m}$ was built. Bathymetry was populated with data from single-beam surveys collected in 2011 [4] and IBCAO [42]. Although highly dynamic, the position of Bernard Spit was kept constant with a footprint that was representative of the 2010 decade. The model was run for 2000 separate sea states representing possible combinations of winds and waves at the ERA5 offshore point for the 1979-2019 time period. The representative sea states were determined using a clustering technique developed by [43]. WP at five locations fronting 
the bluffed Barter Island coast was computed from all 2000 SWAN runs and subsequently divided by WP at the offshore input point to derive WP reduction factors, $\alpha$,

$$
\alpha^{i}=\frac{W P_{r}^{i}}{W P_{O F}^{i}} \text { and } \bar{\alpha}=\frac{\sum_{i=1}^{N} \alpha^{i}}{N}
$$

where the $i$ subscript denotes individual sea states, OF is the offshore (ERA5) point, $r$ is one of the five inshore points along the $2 \mathrm{~m}$ isobath fronting one of the five bluff sections (Figure $3 \mathrm{~A}$ ), $N$ is the total number of sea states, and mean values are denoted by the overbar.

The mean valued reduction factors were applied to the hourly ERA5 time series of computed WP to generate inshore WP between subsequent measurements of bluff top positions (denoted with a superscript $T$ ).



Figure 3. (A) Color-coded shoreline positions for 4 selected historical time periods, overlain on 1955 imagery. Note the formation of the inlet on the eastern Bernard Spit and the southerly retreat and westward extension of both Bernard Spit and western Barter Island between 1947 (black line) and 2020 (red line). Imagery base from USGS Earth Explorer. (B) Net shoreline movement of Barter Island and Bernard Spit between 1947 and 2020 overlain on 2020 imagery. The lengths of the colored lines show the total distance the shoreline moved over the study period. Red lines indicate retreat and blue lines progradation. The area eroded on western Bernard Spit (P1) is nearly equal to the area deposited in P2. Isobaths represent circa 2011 bathymetry [4]. Imagery base is Alaska High Resolution Imagery (https://gis.data.alaska.gov/pages/Imagery\% 20Program accessed on 1 October 2021). 


\section{Results}

\subsection{Shoreline Change}

The sand and gravel shorelines of Barter Island and adjacent barrier island, Bernard Spit, showed a consistent pattern of southerly (landward) retreat and westerly extension through time (Figure 3A). Between 1947 and 2020 the east and west ends of Bernard Spit eroded and/or migrated to the south while the central portion of the island remained relatively stable. The western terminus of the island retreated up to $470 \mathrm{~m}$ and extended nearly $980 \mathrm{~m}$ to the west. The total area lost (P1 in Figure 3B) and gained (P2 in Figure 3B) on the western terminus were nearly equivalent $\left(332,000\right.$ and $329,000 \mathrm{~m}^{2}$, respectively), indicating a relative balance of subaerial sediment redistribution. A volumetric comparison of the observed change was not possible because of lack of available elevation data prior to 2009. The eastern terminus of the island was breached, and a persistent inlet formed, sometime between 1979 and 2004, ultimately resulting in over $600 \mathrm{~m}$ of southerly migration of the eastern terminus by 2020 .

On Barter Island, maximum beach widths were present at the flanks of the island where east-west trending spits formed, by way of longshore transport driven by variations in wave direction at the terminus of the spits. The presence and westward migration of Bernard Spit has increasingly provided shelter from incident wave energy to eastern Barter Island, resulting in relative stability of the eastern spit over the study period. The beach fronting the community of Kaktovik and adjacent lagoon, began prograding northward, and progressively westward, beginning sometime between 1987 and 2000. By 2020 a relatively persistent beach, over $100 \mathrm{~m}$ wide, was present as far west as the radar station (Figure 3A). The shoreline fronting the coastal bluffs to the west of the radar station generally retreated at a rate similar to the eroding bluffs, while maintaining a narrow, but seasonally variable width of between 0 and approximately $30 \mathrm{~m}$ [29]. Similar to Bernard Spit, Barter Island's western spit, changed considerably over the study periods, retreating southward as much as $277 \mathrm{~m}$, eroding into and depositing on top of the low-lying vegetated wet-sedge habitat, and extending over $1 \mathrm{~km}$ to the southwest (Figure 3B).

The rate of migration of the western termini of the western Bernard and Barter Island spits were estimated by measuring the linear distance between the westernmost point on the spit in 1947 and the westernmost point in each subsequent year (Figure 4). Results of this approach showed relatively similar patterns and rates of change on both spits but with a fundamental shift in behavior between 1987 and 2000. Prior to 1987 rates of westward migration of the west Barter Island spit were slightly higher than west Bernard Spit, with rates of 7 and $9 \mathrm{~m} / \mathrm{yr}$, respectively. Between 1987 and 2000, the western node of the Barter Spit moved to the north east by approximately $400 \mathrm{~m}$ before continuing a near linear and continuous westward migration of near $38 \mathrm{~m} / \mathrm{yr}$. The rate of migration rate similarly increased substantially on west Bernard Spit to $32 \mathrm{~m} / \mathrm{yr}$ but without a notable shift in the node of migration. 


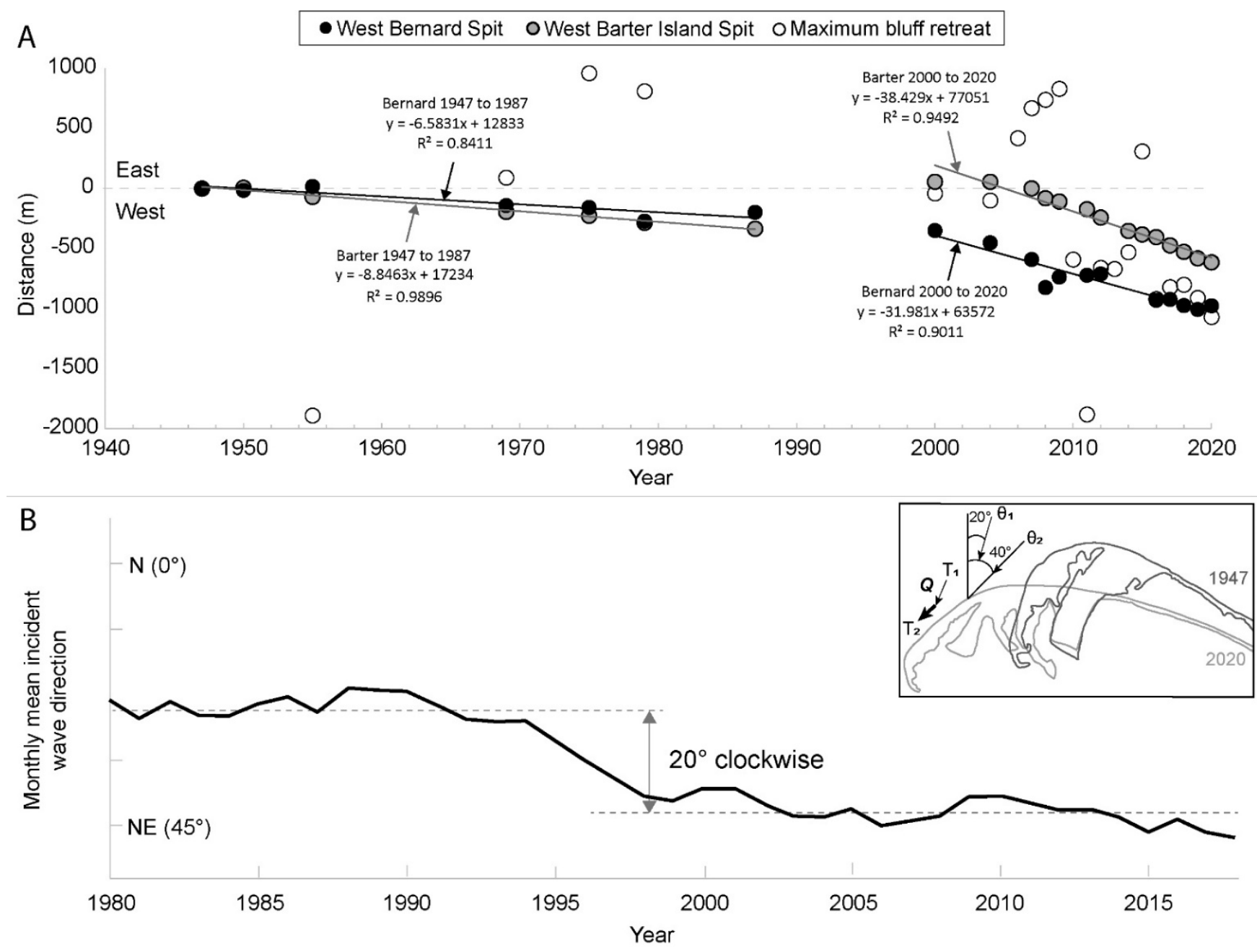

Figure 4. (A) Plot showing the cumulative distance of westward migration of the west end of Bernard Spit, the western Barter Island spit, and the transect of maximum bluff retreat from 1947 (spits) or 1950 (bluffs) and 2020. Simple linear regression equations and $\mathrm{R}^{2}$ values are plotted for two behaviorally similar time periods as observed on the spits: 1947-1987 and 2000-2020; (B) Plot of the change in monthly mean incident wave direction at the ERA5 grid cell $\sim 30 \mathrm{~km}$ offshore and in $20 \mathrm{~m}$ water depth between 1980 and 2019, showing a 20 degree clockwise rotation. Inset plot shows these angles in relation to Bernard Spit.

\subsection{Coastal Permafrost Bluff Change}

Barter Island's ocean exposed coastal permafrost bluffs retreated continuously over the study period, reaching a maximum distance of $163 \mathrm{~m}$, and average distance of $114 \mathrm{~m}$, between 1950 and 2020 (Figure 5). The mean long-term bluff retreat rate of $1.6 \pm 0.1 \mathrm{~m} / \mathrm{yr}$ (range 0.3 and $2.2 \mathrm{~m} / \mathrm{yr}$ ) was similar to the long-term mean shoreline retreat rate measured along the Alaskan Beaufort Sea Coast (1.8 $\pm 0.02 \mathrm{~m} / \mathrm{yr}, 1947-2012)$ [9] and nearly two times higher compared to mean shoreline retreat rate on the adjacent Canadian Yukon Beaufort Sea coast $(0.7 \pm 0.2 \mathrm{~m} / \mathrm{yr} ; 1951-2011)$ [44]. The long-term record at Barter Island was also punctuated by individual years with mean annual retreat rates that were more than 4 times higher than the long-term rate (Table 2). The highest rate of retreat at a single transect $(21.3 \pm 1.9 \mathrm{~m} / \mathrm{yr})$ was measured between July 2012 and August 2013 with a mean rate of retreat for all transects measured during the same time period of $6.6 \pm 1.9 \mathrm{~m} / \mathrm{yr}$. The region of maximum retreat over the long term was measured near the center of the study area, from approximately 1060 to $1840 \mathrm{~m}$ from the eastern boundary of the bluffs. Minimum long-term retreat distances were measured along a $\sim 350 \mathrm{~m}$ long section of bluffs on the eastern end of the study area fronted by a prograding beach where retreat has been 
near zero since 2006. The only significant accretion or progradation of the bluff edge is associated with construction of a landfill at the LRRS between 1955 and 1969 (Figure 5).
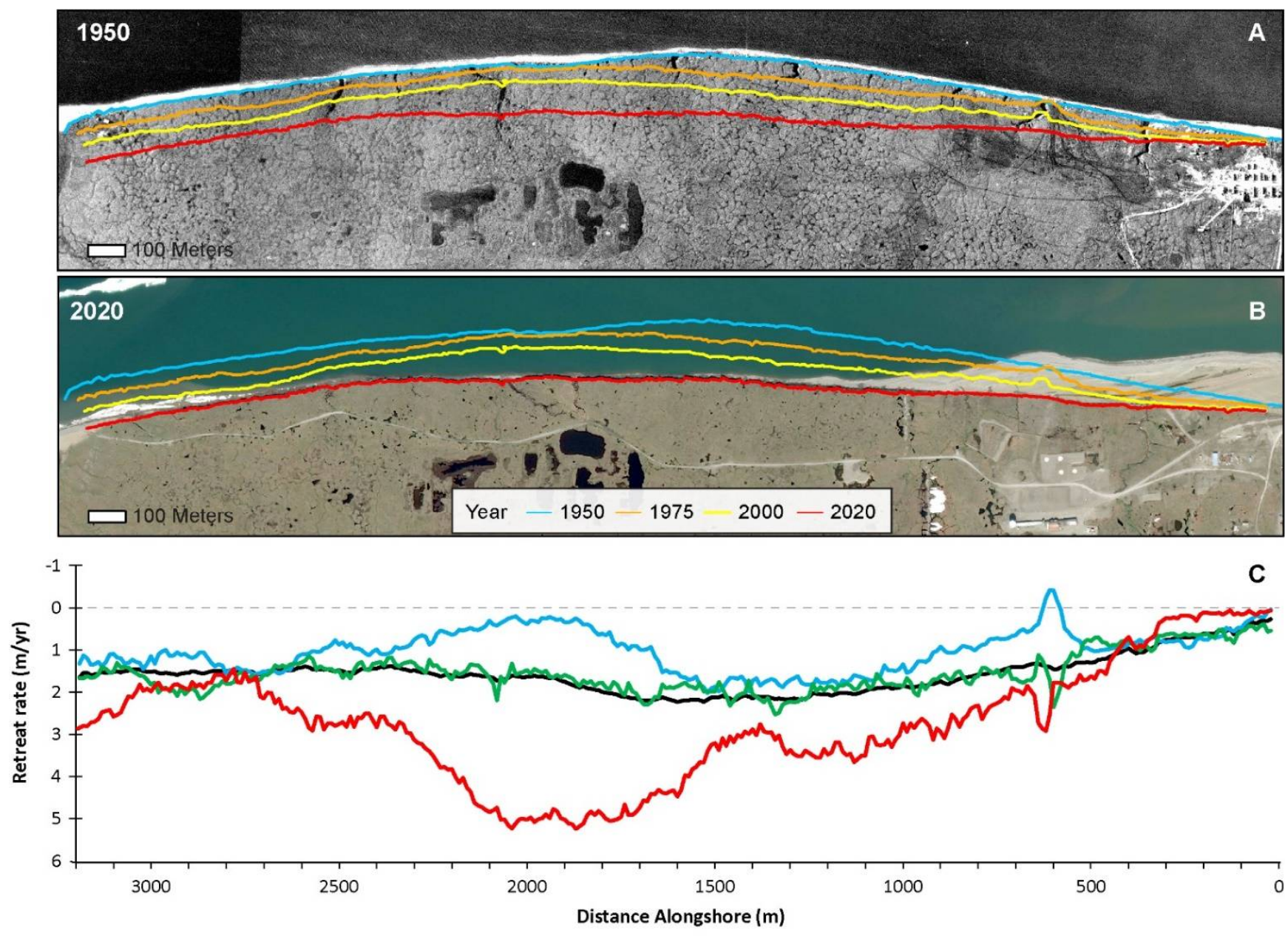

1950-2020 (yr = 70, mean $=1.6 \pm 0.1 \mathrm{~m} / \mathrm{yr} ; \mathrm{SD}=0.4)$

-1950-1975 (yr = 25, mean $=1.1 \pm 0.2 \mathrm{~m} / \mathrm{yr} ; \mathrm{SD}=0.6)$

1975-2000 (yr = 25, mean $=1.4 \pm 0.2 \mathrm{~m} / \mathrm{yr} ; \mathrm{SD}=0.4)$

$2000-2020(\mathrm{yr}=20$, mean $=2.7 \pm 0.1 \mathrm{~m} / \mathrm{yr} ; \mathrm{SD}=1.4)$

Figure 5. Rates and patterns of bluff change at Barter Island from 1950 to 2020. (A,B) show the same extent with bluff edge positions from 4 years overlain on images from 1950 and 2020, respectively. (C) is the same alongshore extent, with the mean decadal rate of change at each transect location plotted. The black line is the long-term 70 year mean. The record is entirely erosional except for a small extent of accretion between 1950 and 1979 associated with the construction of a landfill at the radar station. Between 2000 and 2020, retreat rates were substantially higher than the previous 25 year time periods and the rate of change on the easternmost side of the bluffs approaches 0 as a relatively persistent beach formed, providing protection to the coastal bluffs from seasonal wave attack. Imagery base is Alaska High Resolution Imagery RGB (https://gis.data.alaska.gov/pages/Imagery\%20Program accessed on 1 October 2021).

\subsubsection{Long-Term Decadal Scale Bluff Change}

Comparison of bluff change rates calculated over near similar length decadal time periods, constrained by limited data prior to 2000 (1950-1975, 1975-2000, and 2000-2020), showed a steady increase in retreat rates through time, with a near 3-fold increase in mean (and maximum) rates of retreat over the last two decades compared to the two previous 25 year time periods (Table 2). The mean 1950 to 1975 retreat rate of $1.1 \pm 0.2 \mathrm{~m} / \mathrm{yr}$ increased slightly, but significantly, to $1.4 \pm 0.2 \mathrm{~m} / \mathrm{yr}$ from 1975 to 2000 (similar to the 70 year mean of $1.6 \pm 0.1 \mathrm{~m} / \mathrm{yr}$ ), then nearly doubled to a rate of $2.7 \pm 0.1 \mathrm{~m} / \mathrm{yr}$ from 2000 to 2020 (Figure 5). Variability also increased considerably during this final time period, as indicated by an increase in standard deviation of the rates from 0.4 to 1.4 . 
Figure 5C shows the spatial variability in retreat rates across the study area over these same decadal time periods and compared to the 70 year long-term rate. Change rates from the earliest time period, 1950-1975, were consistently lower than the long-term rate. The construction of the landfill was responsible for the accretion around $750 \mathrm{~m}$, and the highest rates of retreat were measured around $1500 \mathrm{~m}$ from the east end of the bluffs. Change rates from 1975 to 2000 were similar to the 70 year mean rate, and the highest rates of retreat were measured around $1300 \mathrm{~m}$ from the east end of the bluffs. Between 2000 and 2020, change rates were comparatively much higher across the study area except for the easternmost bluffs where retreat rates approached zero. The highest rates of retreat were measured approximately $2000 \mathrm{~m}$ from the east end of the bluffs. Similar to the western termini of Bernard Spit and Barter Island spit, the apex or node of the island, which was generally the region of highest retreat rates, also migrated to the west, approximately $800 \mathrm{~m}$ since 1950, resulting in an overall straightening of the shoreline line, possibly caused by divergence in longshore transport due to changes in regional or local incident wave directions (Figure 4).

Quantifying the rate or pattern of this apparent migration in the node of maximum erosion was not as straightforward for the coastal bluffs as compared to the sand and gravel shorelines, likely because of the more complex relationship between coastal geology and physical processes driving erosion. The distance between the location of maximum retreat measured over each interannual time period and the location of overall maximum bluff retreat measured over the study period (1950 to 2020) is plotted in Figure 6. No significant temporal trends were apparent over the time series; however, a weak but relatively consistent trend, similar to the spits, was apparent after 2010 through 2020 (Figure 4).

A quartile distribution of total (70 year) bluff retreat distance at individual transects illustrates the spatial variability across the study region as distinct regions with similar magnitudes of change: Central bluffs (Q4; 136 to $163 \mathrm{~m}$ ), Western bluffs (Q3; 107 to $136 \mathrm{~m}$ ), and Eastern bluffs, which are further subdivided by moderate (Q3; 102 to $136 \mathrm{~m})$, low (Q2; 59 to $102 \mathrm{~m}$ ), and very low (Q1; 14 to $59 \mathrm{~m}$ ) retreat rates (Figure 7A). The cumulative distance of change for all transects at each bluff-edge observation date illustrates the temporal variation of the bluff over the 70 year study period (Figure 7B). Fitting linear regression lines to the full dataset, the quantile divisions, and Transect 136, the transect with the highest measured retreat rate from 2019 to 2020, illustrates how each of these spatially varying populations are retreating compared to the average rate of the entire bluff. Applying a 2nd order polynomial linear regression improved the fit of the curves by 0.2 to $4 \%$, particularly for Q3 and Q4 locations, supporting other observations that retreat rates are accelerating through time.

\subsubsection{Short-Term Interannual Bluff Change}

Short-term interannual bluff change rates showed large temporal and spatial variations, which are characteristic of highly dynamic coastal environments. Although comparison of endpoint rates of change calculated on temporally adjacent bluff positions can provide useful information on interannual variability of the natural system, care must be taken when extrapolating these observations in the context of interpreting meaningful or sustained change to coastal behavior or response to environmental drivers. In the dynamic coastal environment, rates of change calculated over a shorter period of time can be highly skewed by annual rates that are anomalously high (or low) but will generally always be higher in magnitude and variability (higher standard deviation) compared to longer-term measurements, due to the averaging effect over time. Here, we present rates and patterns of interannual change, and in the context of longer-term averages, to highlight significant changes in temporal and spatial trends. 


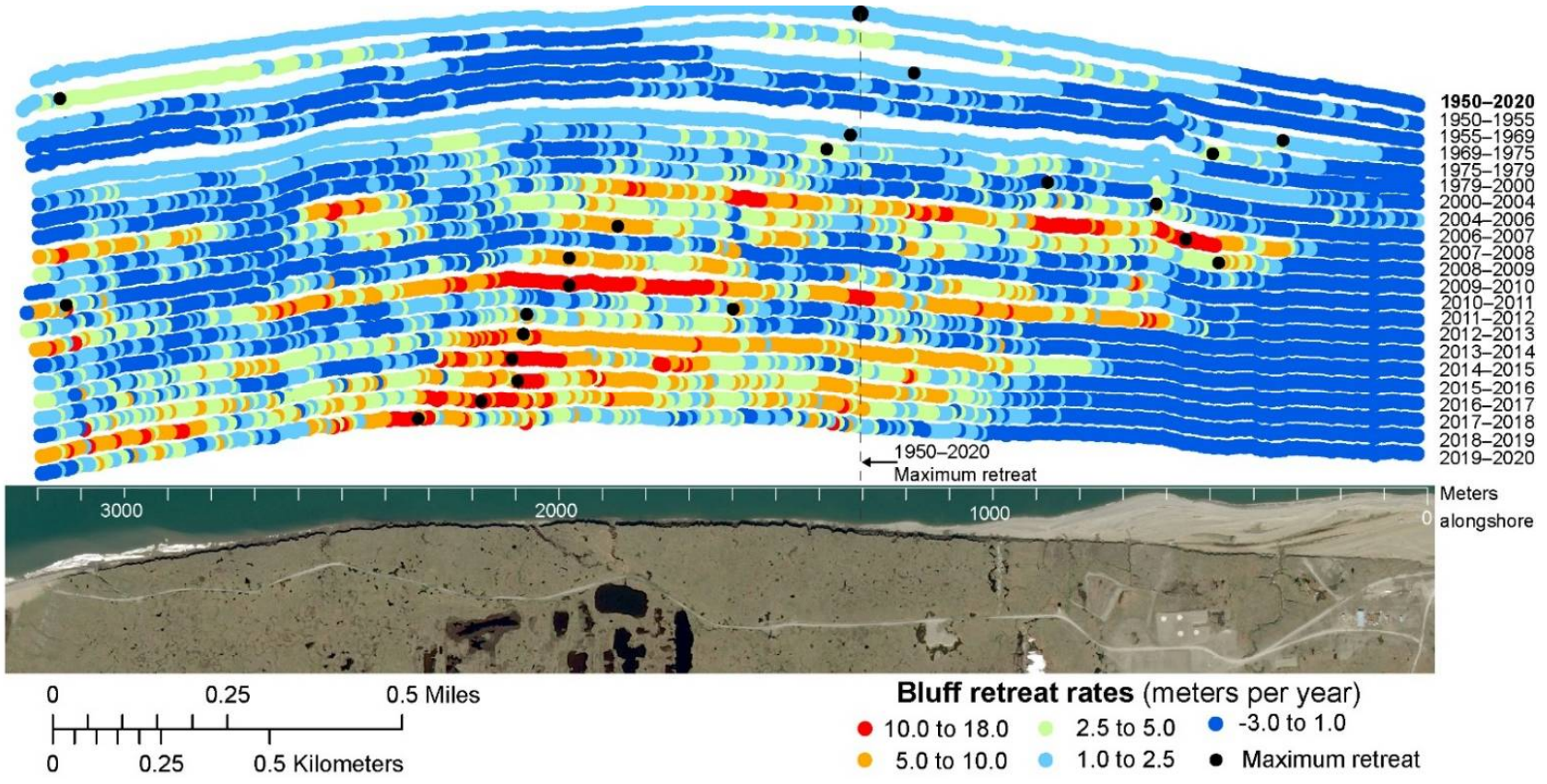

Figure 6. Interannual bluff retreat rates at Barter Island. Black circles identify the location of the maximum retreat for each time period. Prior to 2012-2013, maximum rates moved back and forth from the east to west side of the bluffs but after 2009-2010, maximum erosion was nearly consistently focused north of the large thermokarst lakes and erosional gullies and showed a relatively consistent westward translation of the zone of maximum retreat. Imagery base is Alaska High Resolution Imagery RGB (https:/ / gis.data.alaska.gov/pages/Imagery\%20Program accessed on 1 October 2021).
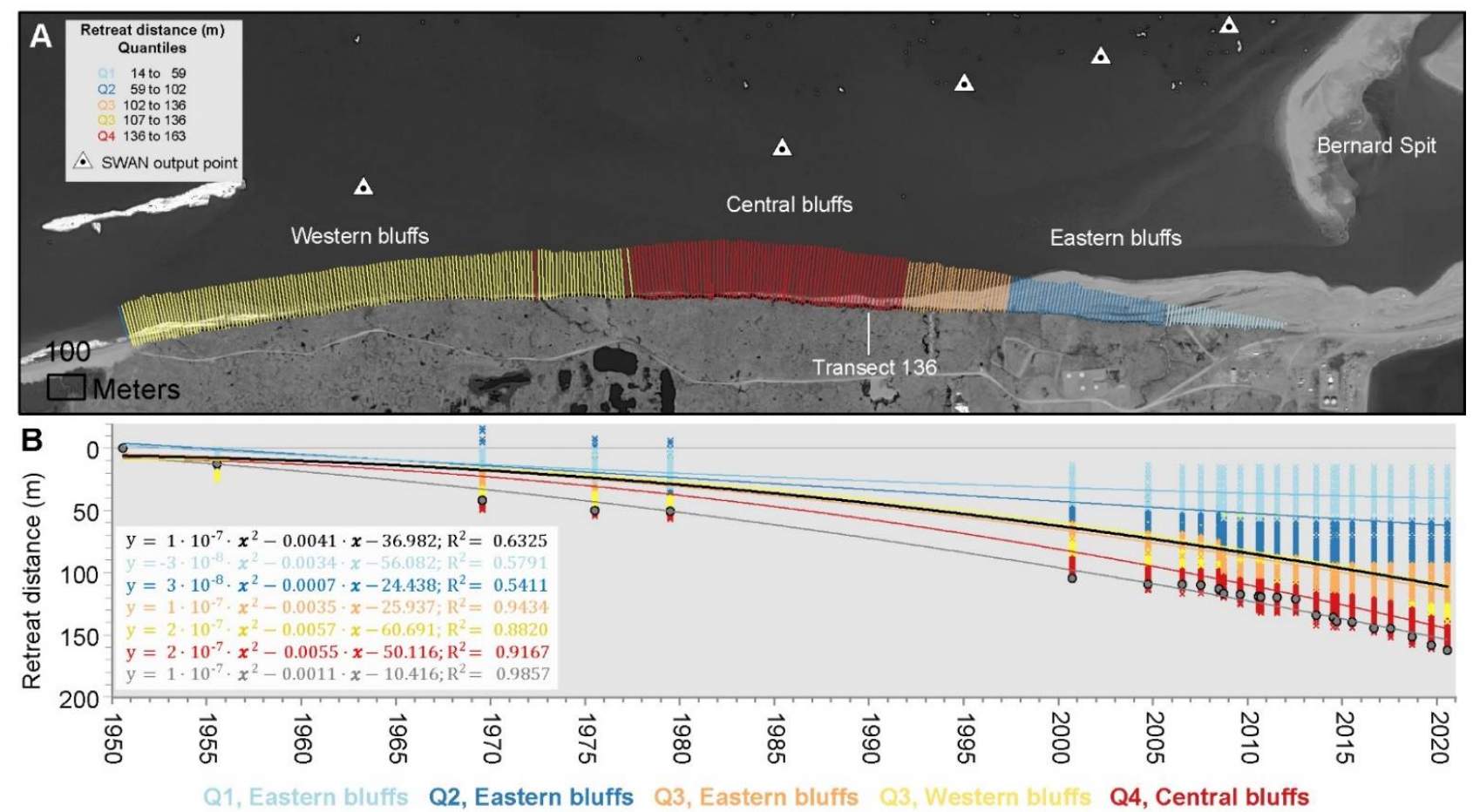

-All transects $\circ$ Transect 136

Figure 7. (A) Quartile distribution of bluff retreat distance identified by separate colors: Central bluffs (Q4), Western bluffs (Q3), and Eastern bluffs, which are further subdivided by moderate (Q3), low (Q2), and very low (Q1) retreat rates. (B) Cumulative bluff retreat distances for all transects within a region and at each observational time period and equations for polynomial linear regression and $\mathrm{R}^{2}$ values. Imagery base is modified from Alaska High Resolution Imagery RGB (https:/ / gis.data.alaska.gov/pages/Imagery\%20Program accessed on 1 October 2021). 
Annual to semiannual (hereafter, interannual) bluff change rates were calculated between adjacent years of bluff position data for a total of 21 comparison pairs, ranging between 0.8 and 21.3 years, with a higher frequency after the year 2000 and near annual comparisons after 2006 (Table 2, Figure 8). Prior to the year 2000, mean short-term bluff retreat rates for four of the five time periods were lower $(0.7 \pm 1.1$ to $1.5 \pm 0.2 \mathrm{~m} / \mathrm{yr})$ but not significantly different than the long-term 70 year mean retreat rate of $1.6 \pm 0.1 \mathrm{~m} / \mathrm{yr}$. The exception was the earliest time period, 1950-1955, which was higher $(1.9 \pm 0.9 \mathrm{~m} / \mathrm{yr})$ but also not significantly different than the mean long-term rate. After the year 2000, mean short-term rates ranged from $0.9 \pm 2.3$ to $6.6 \pm 1.9 \mathrm{~m} / \mathrm{yr}$, and 11 of 16 years had rates higher than the 70 year mean. After 2015, mean annual change rates were from 1.4 to 2.5 times greater than the 70 year mean (Table 2, Figure 8).

Change rates were calculated for five, 4 year time-averaged periods between 2000 and 2020 to reduce the high variability in annual change rates inherent in the post-2006 data. Mean bluff retreat rates for these 4 year time periods ranged from 1.8 to $3.5 \mathrm{~m} / \mathrm{yr}$, were from 1.1 to 2.2 times higher than the 70 year mean retreat rate and showed a consistent and increasing trend through time where retreat rates doubled over the 20 year period (Figure 8). These results suggest that a steady increase in bluff retreat rates observed since 2000, and consistently since 2015, indicate an acceleration in bluff erosion that is independent of large spatial and temporal variations observed on an annual basis.

Rates of retreat measured on individual transects across the study area for each interannual time period (Figure 6) illustrate the extremely high spatiotemporal variability of the bluff change dataset. Interannual maximum retreat rates, shown by the black circles in Figure 6, shifted back and forth from east to west across the study area until about 2009-2010, when maximum erosion was almost consistently focused north of the large thermokarst lake and erosional gullies, and trending toward the west. Lower overall rates were characteristic of the longer time-averaged periods ( $>4$ year; prior to 2004); however, 2010-2011, 2013-2014, and 2014-2015 were also relatively low. Very high rates were apparent in 2007-2008, 2012-2013, and after 2015-2016. After 2015, high retreat rates were focused along shorter segments of coast. The westward reduction in bluff retreat rates on the eastern bluffs associated with the deposition of the wide fronting beach was apparent beginning around 2006. The bluffs at the western of the study area showed moderately high erosion rates as far back as 1950-1955, but the transition to intermittently extreme and generally increasing erosion rates began in 2007.

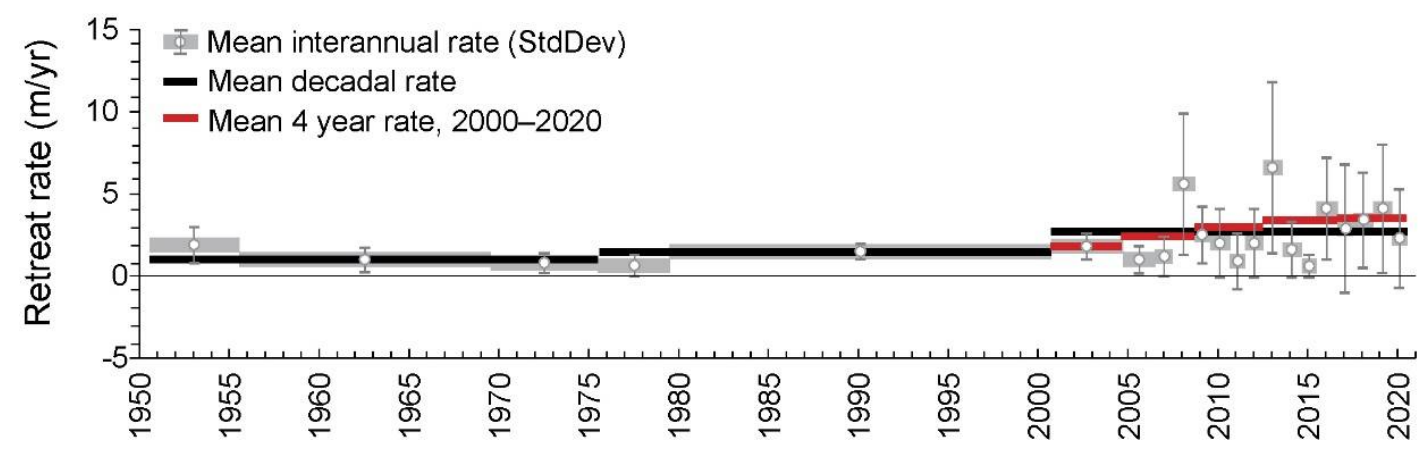

Figure 8. Mean annual retreat rate and standard deviation for the time periods between adjacent bluff datasets (gray), with mean long-term decadal rates (black) and 4 year mean rates from 2000 to 2020 (red) show highly variable, but consistent increase in retreat rates over the study period.

\subsection{Assessment of Physical Drivers: Waves and Temperatures}

Cumulative wave power (WP) calculated at the western bluffs site, the duration of the open-water season (OWS; within at least $70 \mathrm{~km}$ of the coast) derived from the ERA5 reanalysis, and positive degree days and SSTs (PDD and PDSST) derived from the ERAI reanalysis that were normalized to the 30 year mean (1979-2009) highlight long-term 
variability in these potential drivers of coastal change (Figure 9A,B). WP and OWS tracked similarly over the record, illustrating their interdependence with one another [3,45]. The two showed a consistent negative anomaly, or phase, prior to 1987, followed by a mixed phase with both positive and negative excursions from the 30 year mean. A positive phase began in 2003 that was continuous and generally increasing through time, with the exception of years 2013, 2019, and 2020 (Figure 9A). PDD and PDSST generally tracked together over the analysis period and, similar to WP and OWS, showed a negative phase prior to 1987, a mixed phase that extended through 2009, followed by a sharp increase in temperature that persisted from 2010 to 2018 (Figure 9B).

Despite a large year-to-year variability in the first and, to a lesser extent, the last day of open water, the overall duration of the OWS near Barter Island has more than tripled from $\sim 40$ days in the early 1980s to $\sim 140$ days by 2020 (Figure 9C). Linear trends indicate the earlier onset of spring to early summer ice melt (1.5 days/year) slightly outpaces a later freeze up in the fall (1.1 days/year) This expansion in the duration of the open water season is comparable to studies elsewhere along the Alaskan Beaufort coast $[4,7,46]$ although Overeem et al., 2011 noted a more rapid expansion in the fall, compared to the spring and summer of 2011.

Computed ratios of inshore to offshore wave power along the five distinct bluff sections (Figure 7A) are shown in Figure 10. The wave energy reduction coefficients were computed separately for five offshore incident wave direction bins (ranging from east (90) to west (270)) and show that west and northwesterly incident waves, once propagated to the shore ( $2 \mathrm{~m}$ water depth), underwent greater loss of energy along the easternmost bluff section compared to the other bluff sections. For these wave conditions, inshore wave energy at the easternmost bluff section was $\sim 60 \%$ of the offshore energy, whereas along the western section, the wave energy was $~ 80 \%$ of the offshore energy (a reduction of $20 \%$ compared to $40 \%$ for the easternmost section). For the most easterly incident waves, the presence of Bernard Spit blocks much of the wave energy from reaching any section of the bluffed Barter Island coast. The blocking effect decreases with increasingly westerly incident waves as shown with the relative increase in $\alpha$ (alpha) along the central and western bluffs. Whereas Bernard Spit does not directly block north to west incident wave energy, the presumed longshore sediment transport and westward migration of Barnard Spit's west terminus has led to a wider and milder sloping seabed fronting the eastern bluffs, resulting in greater wave refraction and energy dissipation along that section of coast compared to the central and western sections (see bathymetric contours in Figure 3B).

Median wave power values were applied to a continuous hourly hindcast (1979 through 2019) of offshore ERA5 wave conditions to estimate annual cumulative wave power fronting each of the five bluffed coastal sections (Figure 11). The presence of landfast and pack ice during most of the year limited the analysis period to late May through early December. Annual variations in timing of spring season sea ice breakup in conjunction with wind energy of sufficient magnitude to generate waves can be inferred from the shift in the gray lines along the $x$-axes of Figure 11A-E. The end of the open water season, when sea ice has again encroached upon the coast, can be inferred from the horizontal flattening, indicating no further wave energy for that particular year. Superimposed upon the individual annual years are solid-colored lines showing the long-term mean, 1979 through 2009, and averages over the latter 10 years split into two 5 year time periods, 2010 through 2014 and 2015 through 2019. The results indicate that inshore wave power has increased four-fold over the past decade compared to the long-term mean, and that the increase is continuing (purple line $>$ blue line), commensurate with the increasing bluff retreat rates. 

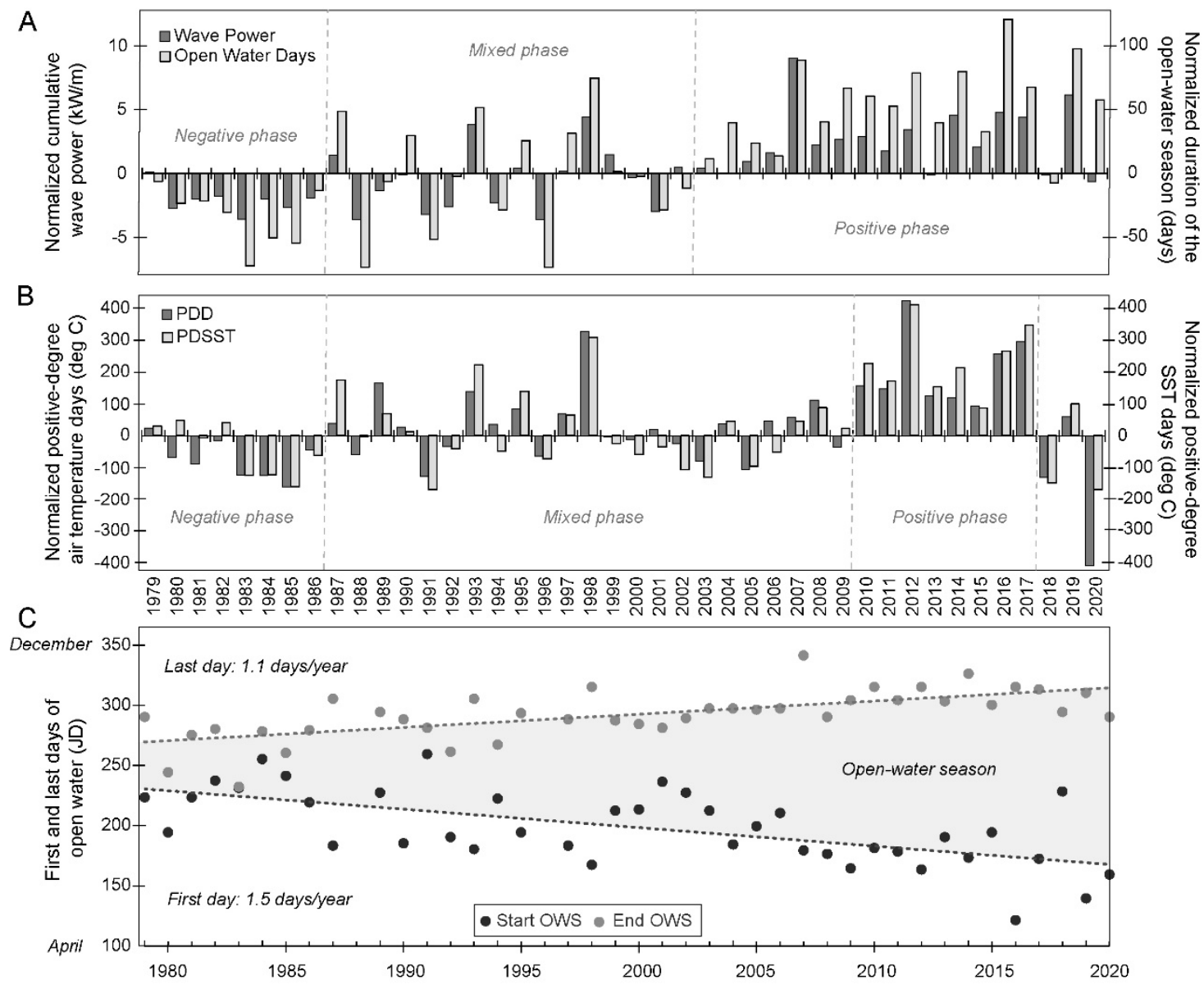

Figure 9. (A) Cumulative wave power (WP) and the duration of the open-water season (OWS) normalized to the 1979-2009, 30 year mean; (B) positive degree day air and sea surface temperature (PDD and PDSST) conditions normalized to the 1979-2009, 30 year mean; (C) First and last days of open water between 1979 and 2020 and linear trends of their rate of expansion. WP and OWS data calculated from daily means derived from the ERA5 reanalysis data, with the wave power downscaled to the 'west bluff' nearshore point location using the inshore:offshore ratios presented in Figure 10. PDD and PDSST data were calculated from daily means derived from the ERA-I reanalysis data.

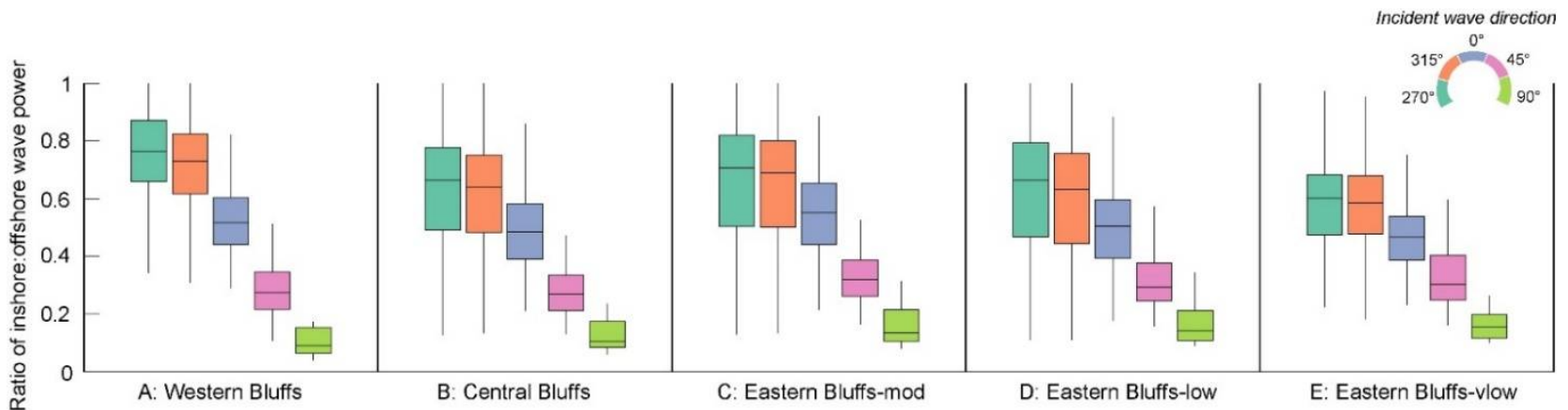

Figure 10. Ratio of inshore to offshore wave power along five distinct sections of Barter Island as a function of offshore incident wave directions. WB, EB, and CB denote the western, eastern, and central bluffs, respectively. Eastern bluff sections are further divided by moderate to very low bluff recession rates (see Figure 7a). Ratios were computed from wave model runs of 2000 individual events of varying wind and offshore wave conditions. 

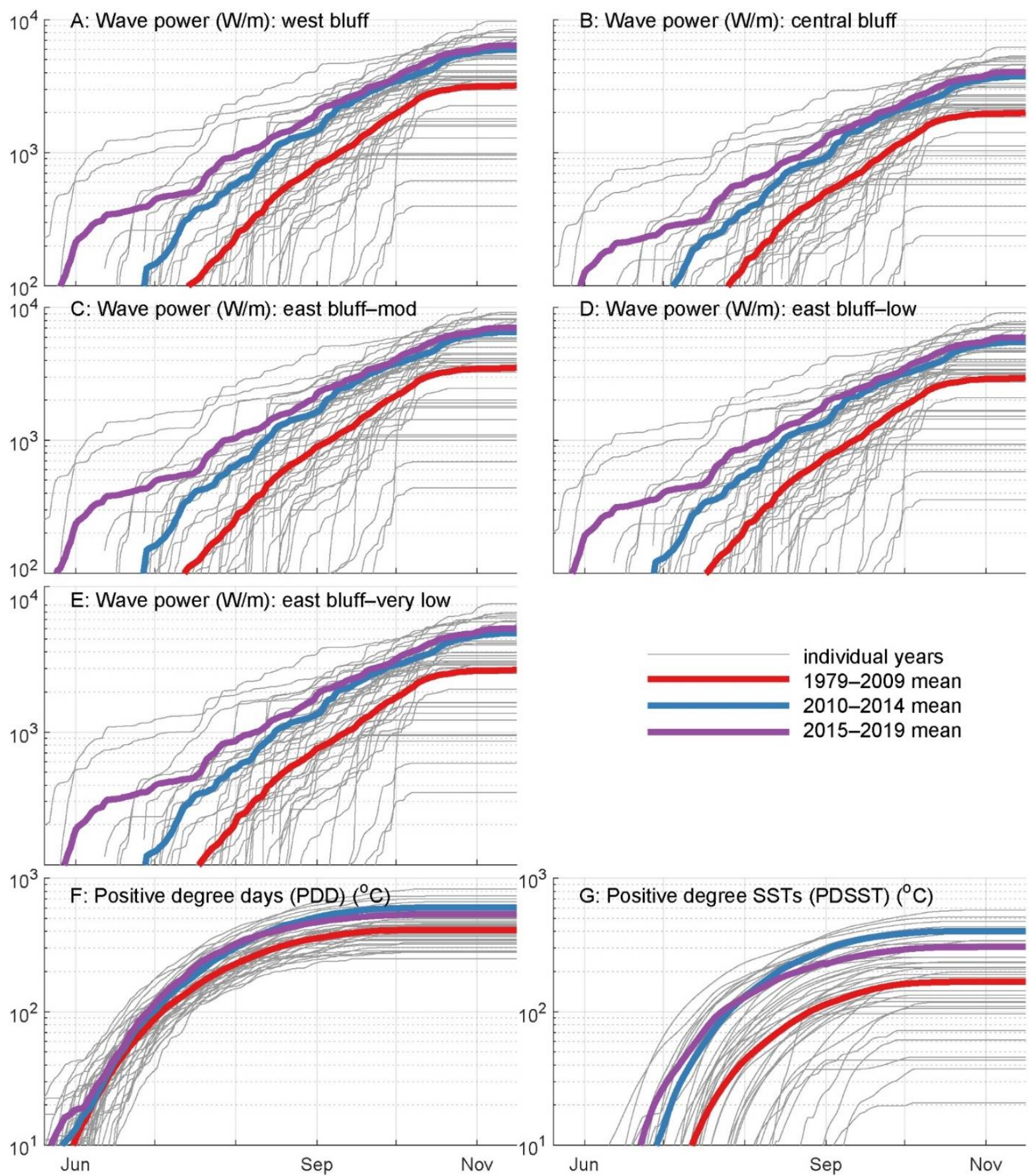

Figure 11. Annual cumulative sums of inshore wave power, positive degree days (PDD), and positive degree sea surface temperatures (PDSST). Solid lines show the mean annual cumulative sums calculated over the 30 year reference time period 1979-2009 and subsequent 5 year time slices from 2010 through 2014 and 2015 through 2019.

To evaluate the potential for ambient air and seawater temperatures as drivers of thermal denudation and thawing at the base of the bluff during contact, cumulative positive air and sea surface temperature degree days (PDD and PDSST) were computed (Figure 11F,G). Because SSTs are indicative of sea ice presence, the spread of the PDSSTs along the monthly $x$-axis and time at which the curves flatten (indicating cooling and refreeze) were, as expected, similar to the WP plots. The percent change was, however, half that of WP, with 230\% increase for the most recent period relative to the long-term mean. Finally, considering the PDD as a potential indicator for thermal denudation, the percent increase relative to the long-term mean was in the order of $160 \%$. 
Bluff retreat rates are plotted against cumulative WP, PDD, and PDSST in Figure 12. The physical driver variables (WP, PDD, PDSST) were normalized by the long-term means multiplied by the bluff heights $\left(D_{i}\right)$ to obtain units of meters to match the bluff retreat dimension. Measured bluff heights at each transect and for each time point beginning in 2009 were used when available; bluff heights were assumed to be constant for the preceding years when no data were available. Statistically significant $(p$-value $<0.005)$ least-squares linear fits were found for WP $\left(r^{2}=0.92\right)$ and PDSST $\left(r^{2}=0.90\right)$ and only after removal of at least five outlier points for PDD $\left(r^{2}=0.37\right)$. (Figure 12A,B). To better characterize the relative contributions of each driver to the measured retreat, a multilinear regression with normalized WP, PDD, and PDSST each multiplied by $D^{i}$ was performed. The resulting slopes were found to be 2.93, 0.17, and 0.04 for WP, PDSST, and PDD, respectively $\left(r^{2}=0.92\right.$, Figure 12D). The magnitudes of the slopes indicated that recession was largely driven by mechanical thermoabrasion followed by thermodenudation. Whereas these relationships showed a pattern in an overall sense, the relative contributions of each WP and PDSST to that of PDD was expected to vary significantly across the study area due to nonhomogenous stratigraphy, massive ice content, erratic presence of ice wedges, and evolving surficial gullies.
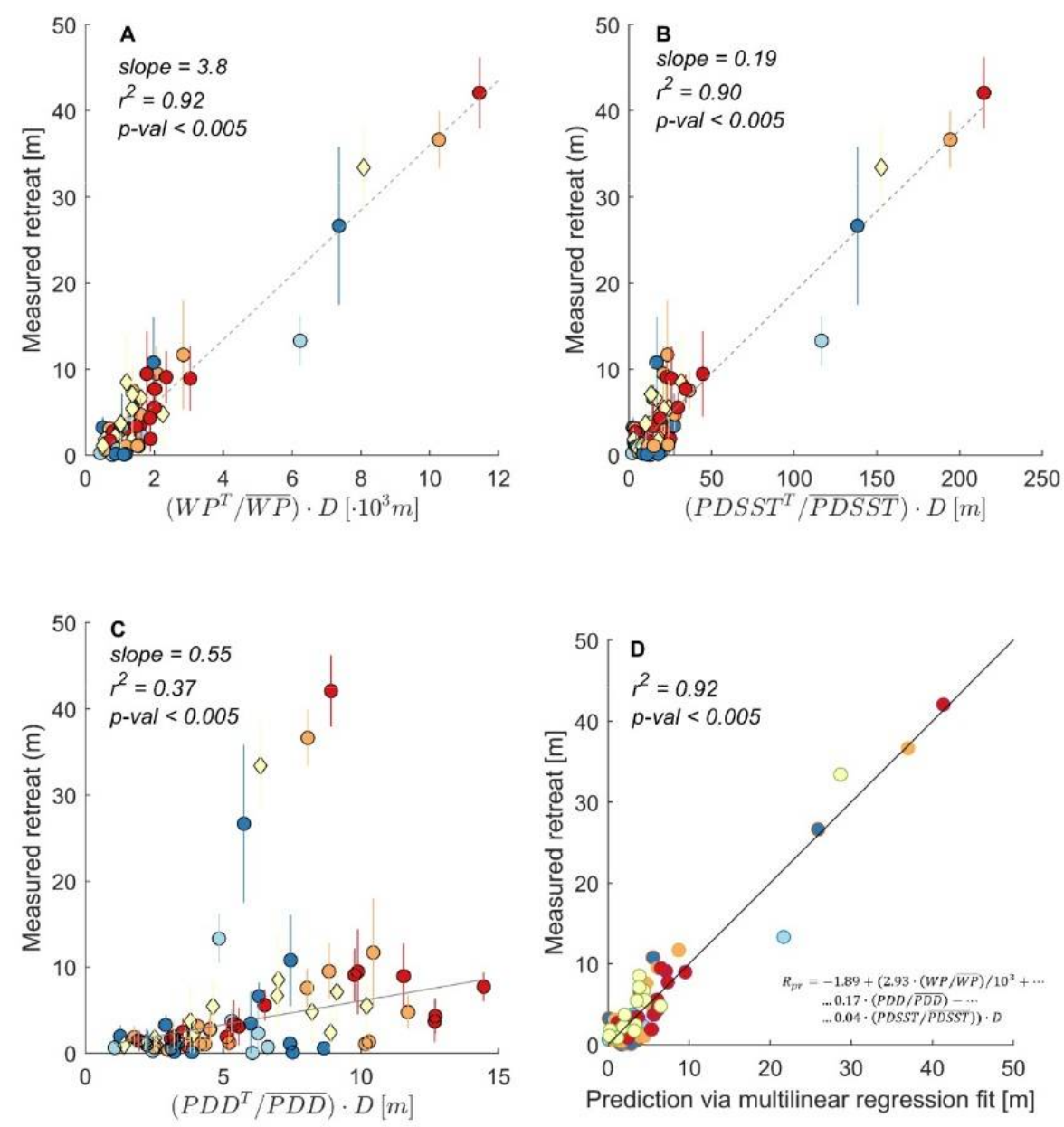

East bluff-very low $\bullet$ East bluff-low $\bullet$ East bluff-mod $\bullet \quad$ Central bluff $\odot$ West bluff

Figure 12. Relationship between bluff recession and physical drivers multiplied by bluff heights. (A) Normalized cumulative wave power (WP), (B) normalized cumulative positive degree days (PDD), (C) normalized cumulative degree day positive sea surface temperatures (PDSST), and (D) linear fit of multiple linear regression between all three physical parameters and measured retreat for 17 distinct time periods between 1979 and 2019, when both bluff recession and physical driver data were available. Solid line in $\mathrm{D}$ is the 1:1 perfect fit; dashed lines in $(\mathbf{A}-\mathbf{C})$ are the least-squares linear fit lines (excluding outliers for PDD). 


\section{Discussion}

The beaches, spits, and barrier islands around Barter Island have continuously retreated to the south and extended to the west through time. Their southerly migration is likely due to a combination of littoral transport, overwash of the islands, and deposition of material into the adjacent lagoons during periods of high waves and elevated water levels. Increasing storm frequency and intensity, combined with sea-level rise, could yield more frequent barrier breaching (breakthroughs) resulting in deterioration of the barrier and reduction in the sheltering capacity provided to the shores of Barter Island. The apparent acceleration in the rate of migration of the western termini of Barter Island and Bernard Spit, beginning sometime between 1987 and 2000 (Figure 4A), may be related to a change in incident wave directions over a similar time period. This also coincides with the 1987 to mid- to late 2000s period between the predominantly negative (prior to 1987) and positive (mid-2000s to 2020) phases of WP, OWS, and temperature anomalies (Figure 9). Mean monthly incident wave directions analyzed from the ERA5 offshore wave data ( $\sim 30 \mathrm{~km}$ offshore in $\sim 20 \mathrm{~m}$ water depth) were primarily from the northeast but appear to have undergone a regime shift, becoming more easterly, between about 1994 and 1999 (Figure 4B). This easterly shift in incident wave energy likely increased the magnitude of littoral transport toward the west. This potential increase in westward transport and extension of Bernard Spit may also be related to the progradation and widening of the beach fronting the community of Kaktovik and the eastern portion of the Barter Island bluffs, as similarly suggested in Kupilik et al. 2020 [47]. It remains unknown whether the directional change is related to underlying climate patterns such as the Arctic Oscillation or persistent climatic changes. The coastal permafrost bluffs at Barter Island showed relatively modest decadal and interannual erosion rates prior to 2008 (mean: 0.7 to $1.9 \mathrm{~m} / \mathrm{yr}$ ), which were similar to the long-term ( 60 year) mean erosional shoreline change rate measured along the Alaskan Beaufort Sea coast (1.8 m/yr; [9]). Beginning in 2008, interannual rates begin to vary widely, from some of the lowest $(0.9 \mathrm{~m} / \mathrm{yr})$ to some of the highest $(6.6 \mathrm{~m} / \mathrm{yr})$ mean rates measured during the study period. After 2015, all years exceeded the long-term rate by more than nearly $50 \%$ ( 2.9 to $4.1 \mathrm{~m} / \mathrm{yr})$.

Does time-averaging over multiple years in the more limited observational data prior to 2000 mask the natural variability of the highly dynamic coastal environments and dilute the earlier calculated rate of change? Do these observations reflect expected decadal scale variability within the natural system? Alternately, do these data suggest the permafrost bluffs and beaches are responding to larger global or Arctic Ocean scale changes in the forcing physical drivers resulting in a 'new normal'? The answers are probably a combination of these and other factors.

Gibbs et al. (2019) [29] investigated 3-dimensional patterns of annual change on the Barter Islands bluffs over a single year that represented typical to slightly below average conditions (2014-2015). Based on the observed morphologic change and temperature and wave-impact records, they proposed seasonal patterns changed where thermal processes (thermodenudation), primarily indicated by bluff dewatering, surface sloughing, and thaw slumping, and formation of overhanging visors, likely occur throughout the ice-free season but with a relatively larger influence earlier in the season when air temperatures are warmer, daylight is longer, storms are less frequent, and waves rarely reach and erode material from the base of the bluffs. As the ice-free season continues through the summer and into early fall, mechanical and thermo-erosional (thermoabrasional) processes begin to dominate as daylight wanes, temperatures decrease, and numerous large and powerful storms driven by low-pressure storms and easterly winds bring storm surge and waves that erode material from the base of the bluffs and undercut the base through thermo-erosional niching. The loss of the bluff toe and niche development leads to destabilization of the overlying bluff material, which can lead to large block failures, rotational slumps, and surface sloughing (Figure 13). Debris aprons develop quickly once waves recede from the base of the bluffs, but likely little change occurs to the bluffs or debris aprons once sea-ice formation is initiated and is present to protect the coast. These patterns and high rates of 
change are believed to be broadly representative of coastal permafrost bluffs found along many high-latitude coastlines worldwide.
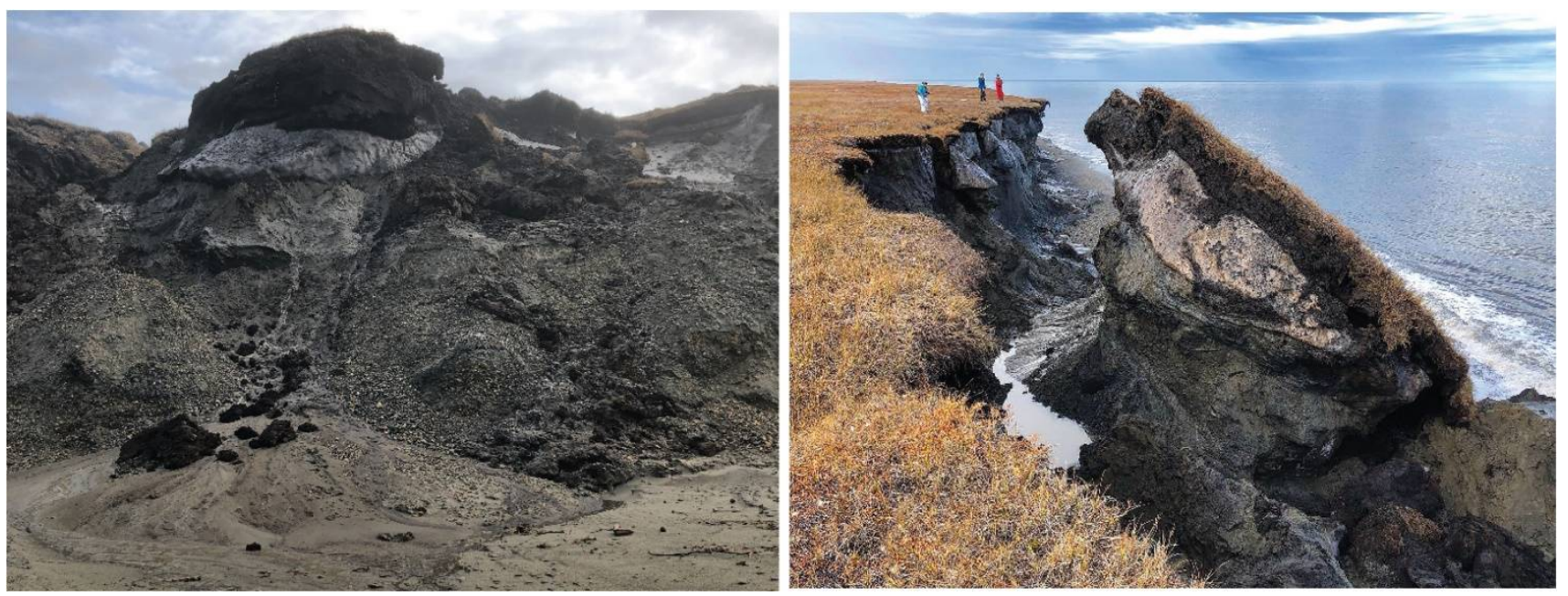

Figure 13. (left) Example of thermo-erosional failure processes of dewatering, debris flow, and thaw slumping of the overlying peat layer (2019, photo by A. Gibbs, USGS). (right) Large block failure resulting from thermomechanical undercutting of the base of the bluffs (2019, photo by C. Johnson, USGS).

A detailed investigation of the physical drivers of coastal change and morphological response trends are complex and beyond the scope of this paper. However, we began to investigate the possible influence of wave power, direction, air temperature, and water temperature on the rates and patterns of Barter Island bluff retreat.

We hypothesize that the apparent acceleration in retreat rates at Barter Island may be related to increases in both thermodenudation and the number of niche-forming and blockcollapsing episodes associated with higher temperatures and longer ice-free conditions in the Beaufort Sea, similar to observations at Drew Point [6].

Comparison between anomalous cumulative annual wave power and temperatures with coastal change rates (Figures 4-6 and 10; Table 2) illustrate the strong influence of these drivers on bluff retreat. The identified long-term increase in wave power and temperatures, particularly after 2003 and 2010, respectively, that also corresponded to a period of high erosion rates at Barter Island, provides a context on decadal-scale climate conditions which can drive coastal change. Further investigation into how broadly these anomalies are recognized along the Arctic coast, as well as potential linkages between the observed anomalies and rates of coastal change with climate indices such as the El Niño Southern Oscillation, Pacific Decadal Oscillation, and/or Arctic Oscillation will help improve the understanding of the interplay between these physical drivers and their influence on coastal change.

Elevated water levels associated with storm surge, high wave energy, and higher air and water temperatures, which are increasing, are all factors that contribute to increased bluff retreat. Teasing apart the relative contribution or importance to annual change from thermo-erosional versus thermomechanical processes is difficult and requires higher frequency driver and response comparisons than included in this paper. However, the volume-loss response due to the two processes are quite different. Thermal processes such as surface sloughing, debris flows, and thaw slumping are typically slow with relatively low volume loss but are temporally consistent. In contrast, thermomechanical processes such as niche formation and block failure are rapid and have the potential to fail very large volumes of material but are episodic. Figure 6 provides a good example of the spatial extent over which block failures can occur (nearly all failure in the central bluff portion of the study area) and the potential volume of material associated with the failures. 
The data and methods employed in this study indicate that the recession was dominated by thermomechanical processes, similar to [47]. In that study, the thermomechanical component was related to wave heights of the 8th power, making that component strongly related to wave conditions and less to denudation. In this study, we found that denudation contributed about a quarter of the amount that thermally driven erosion by water contact contributed and $<2 \%$ compared to mechanical wave erosion.

Only limited data and anecdotal evidence on the relationship between coastal change, storm surge, high wave events, and flooding potential are available for this area. As part of a study to evaluate the stability of Arey Island with respect to sea-level rise and changing storm conditions associated with 21st century climate change, Erikson et al. (2020) [4] derived hindcast (1981 to 2010) and future (2011 to 2100) conditions of the open-water season, wave heights and directions, storm surge, and total water levels using a suite of numerical models. Similar to this study, they noted an expansion in the duration of the open-water season, with nearly equal rates of expansion (1.2 days per year) in the spring and early summer compared to the fall. Their results indicated that the onset and end of the open-water season will shift earlier and later by 20 days per decade and 40 days per decade, respectively, and that the end of the open-water season will extend well into November by the year 2100. Owing in part to the extended open-water season, the number of northwesterly storms affecting the region is expected to increase from less than five events per year prior to 2010 to as many as 30 events per year by the end of the 21 st century. Deep water wave heights are projected to increase with increases in storm duration and wind magnitude and peak wave periods, which have implications for increasing water level runup at the shore, potentially increasing wave and water contact with the base of the bluffs.

\section{Conclusions}

This study used a rich observational dataset to quantify multidecadal to annual rates and patterns of coastal change at Barter Island, Alaska. The study is unique with respect to the high temporal resolution of the observational data as well as the detailed comparison of bluff change with wave power and sea surface temperatures as indicators of thermoabrasion and ambient air temperatures as proxies for thermodenudation.

The beaches and spits of Barter Island and Bernard Spit showed a generally consistent pattern of southerly (landward) erosion and westerly migration. Beach accretion and progradation was observed only fronting the community of Kaktovik and portions of the LRRS. Based on the historical shoreline change trends and the observed shift to the north east of incident wave energy, continued westerly migration of Bernard Spit is likely, and will continue to shelter to the adjacent mainland leading to continued westerly beach accretion and progradation which will likely protect the bluffs from direct waves, leading to reduced erosion rates for the eastern portion of the bluffs.

Permafrost bluff retreat was continuous over the study period, but rapid retreat was episodic and the rate of change was variable through space and time. Comparison of bluff change rates on decadal time periods showed a steady increase in retreat rates through time, with a near three-fold increase in mean (and maximum) rates of retreat over the last two decades compared to the previous five decades. On annual time scales, episodic erosion driven by thermomechanical undercutting of the bluff base results in some of the highest retreat rates measured along the Beaufort Sea coast of Alaska $[6,8,9,29]$.

Interannual bluff retreat rates showed large temporal and spatial variations, which is characteristic of most coastal environments; however, an overall increase in bluff retreat rates since 2000, and consistently high rates since 2015, suggests acceleration in coastal erosion that is independent of the large spatial and temporal variations observed on an interannual basis.

Similar to the western termini of the Bernard Spit and Barter Island spit, the apex or node of Barter Island, which is generally the same region of highest retreat rates, has also migrated to the west, approximately $800 \mathrm{~m}$ since 1950, resulting in an overall straightening 
of the shoreline, possibly caused by a divergence in longshore transport due to changes in incident wave directions and/or the westerly migration of Bernard Spit.

Rates and patterns of bluff retreat were correlated to incident wave energy and air and water temperatures. Wave energy was found to be the dominant driver, followed by sea surface temperatures, and warming air temperatures and can be considered proxies to evaluate thermo-erosion and denudation. Normalized anomalies of cumulative wave energy, duration of open water, and air and sea temperature show at least three distinct phases: a negative phase prior to 1987, a mixed phase between 1987 and the early to late 2000s, followed by a positive phase extending to 2020. The duration of the open water season has more than tripled since 1979, increasing from approximately 40 to 140 days. Acceleration in retreat rates at Barter Island may be related to increases in both thermodenudation, associated with increasing air temperature, and the number of niche-forming and block-collapsing episodes associated with higher air and water temperature, more frequent storms, and longer ice-free conditions in the Beaufort Sea.

Although this study was focused on a relatively small segment of the Arctic coast, the observed rates, patterns, and drivers of permafrost bluff and barrier change are thought to be broadly representative of similar environments found along high-latitude coastlines worldwide. Continued monitoring along with a more comprehensive evaluation of the processes driving coastal change will improve the overall understanding of these complex coastal systems and their future response to a changing climate.

Author Contributions: A.E.G., L.H.E., B.M.R.; methodology, A.E.G.; formal analysis, A.E.G., L.H.E.; resources, B.M.J.; data curation, A.E.G., A.C.E.; writing-original draft preparation, A.E.G., L.H.E.; writing-review and editing, A.E.G., L.H.E., B.M.J.; visualization, A.E.G. All authors have read and agreed to the published version of the manuscript.

Funding: Funding for this study was provided by the U.S. Geological Survey, Coastal Marine Hazards and Resources Program. BMJ was supported by a grant from the National Science Foundation OISE1927553 and the Interdisciplinary Research for Arctic Coastal Environments (InteRFACE) project through the Department of Energy.

Institutional Review Board Statement: No humans nor animals were included in this study.

Informed Consent Statement: No humans nor animals were involved in the study.

Data Availability Statement: The datasets analyzed in this study are available from Gibbs et al., (2020) [40].

Acknowledgments: We remember our colleague Bruce M. Richmond for inspiration and insight in exploring and understanding coastal change in the Arctic and across the globe. Without his contributions, excellent field sense, and unparalleled joie de vivre this work would not have been possible and most certainly not as much fun. We are grateful to the community members of Kaktovik, the City of Kaktovik, and the Native Village of Kaktovik for engaging with us, sharing knowledge, and supporting our research We thank the North Slope Borough and the Kaktovik Inupiat Corporation for permitting us access to their lands for field work. The U.S. Fish and Wildlife Service provided invaluable logistical support. This work was supported by the U.S. Geological Survey, Coastal and Marine Hazards and Resources Program's Coastal National Elevation Database Science Applications, Climate Change Impacts on High-latitude Coasts, and Coastal Change Hazards projects. The authors would like to thank the USGS and anonymous reviewers for thoughtful comments that improved this paper. Any use of trade, firm, or product names is for descriptive purposes only and does not imply endorsement by the U.S. Government.

Conflicts of Interest: The authors declare no conflict of interest.

\section{References}

1. Aré, F.E. Thermal abrasion of sea coasts (part I). Polar Geogr. Geol. 1988, 12, 1. [CrossRef]

2. Günther, F.; Overduin, P.P.; Sandakov, A.V.; Grosse, G.; Grigoriev, M.N. Short- and long-term thermo-erosion of ice-rich permafrost coasts in the Laptev Sea region. Biogeosciences 2013, 10, 4297-4318. [CrossRef]

3. Barnhart, K.R.; Overeem, I.; Anderson, R.S. The effect of changing sea ice on the physical vulnerability of Arctic coasts. Cryosphere 2014, 8, 1777-1799. [CrossRef] 
4. $\quad$ Erikson, L.H.; Gibbs, A.E.; Richmond, B.M.; Storlazzi, C.D.; Jones, B.M.; Ohman, K. Changing Storm Conditions in Response to Projected 21st Century Climate Change and the Potential Impact on an Arctic Barrier Island-Lagoon System-A Pilot Study for Arey Island and Lagoon, Eastern Arctic Alaska; Open-File Report 2020-1142; U.S. Geological Survey: Reston, VA, USA, 2020; 68p. [CrossRef]

5. Frederick, J.M.; Thomas, M.A.; Bull, D.L.; Jones, C.A.; Roberts, J.D. The Arctic Coastal Erosion Problem; SAND2016-9762; Sandia National Laboratories: Oak Ridge, TN, USA, 2016; 122p. [CrossRef]

6. Jones, B.M.; Farquharson, L.M.; Baughman, C.A.; Buzard, R.M.; Arp, C.D.; Grosse, G.; Bull, D.L.; Günther, F.; Nitze, I.; Urban, F.; et al. A decade of remotely sensed observations highlight complex processes linked to coastal permafrost bluff erosion in the Arctic. Environ. Res. Lett. 2018, 13, 115001. [CrossRef]

7. Overeem, I.; Anderson, R.S.; Wobus, C.W.; Clow, G.D.; Urban, F.E.; Matell, N. Sea ice loss enhances wave action at the Arctic coast. Geophys. Res. Lett. 2011, 38, 1-6. [CrossRef]

8. Jones, B.M.; Irrgang, A.M.; Farquharson, L.M.; Lantuit, H.; Whalen, D.; Ogorodov, S.; Grigoriev, M.; Tweedie, C.; Gibbs, A.E.; Strzelecki, M.C.; et al. Arctic Report Card 2020: Coastal Permafrost Erosion; NOAA: Silver Spring, MD, USA, 2020. [CrossRef]

9. Gibbs, A.E.; Richmond, B.M. National Assessment of Shoreline Change: Summary Statistics for Updated Vector Shorelines and Associated Shoreline Change Data for the North Coast of Alaska, U.S.-Canadian Border to Icy Cape; Open-File Report 2017-1107; U.S. Geological Survey: Reston, VA, USA, 2020; 21p. [CrossRef]

10. State of Alaska. Alaska Community Database Online. Available online: https:/ /dcra-cdo-dcced.opendata.arcgis.com (accessed on 11 September 2020).

11. Black, R.F. Gubik Formation of Quaternary Age in Northern Alaska; Professsional Paper 302-C; U.S. Geological Survey: Reston, VA, USA, 1964; pp. 59-91. [CrossRef]

12. Hopkins, D.M.; Hartz, R.W. Coastal Morphology, Coastal Erosion, and Barrier Islands of the Beaufort Sea, Alaska; Open-File Report 78-1063; U.S. Geological Survey: Reston, VA, USA, 1978. [CrossRef]

13. Rawlinson, S.E. Surficial Geology and Morphology of the Alaskan Central Arctic Coastal Plain; Alaska Division of Geological \& Geophysical Surveys: Fairbanks, AK, USA, 1993; 172p.

14. Jorgenson, M.T.; Shur, Y. Glaciation of the coastal plain of Northern Alaska. In Proceedings of the American Geophysical Union Fall Meeting, San Francisco, CA, USA, 15-19 December 2008.

15. Kanevskiy, M.; Jorgenson, T.; Shur, Y.; Dillon, M. Buried glacial basal ice along the Beaufort Sea Coast, Northern Alas. In Proceedings of the American Geophysical Union Fall Meeting, San Francisco, CA, USA, 15-19 December 2008.

16. Kanevskiy, M.; Shur, Y.; Jorgenson, M.T.; Ping, C.L.; Michaelson, G.J.; Fortier, D.; Stephani, E.; Dillon, M.; Tumskoy, V. Ground ice in the upper permafrost of the Beaufort Sea coast of Alaska. Cold Reg. Sci. Technol. 2013, 85, 56-70. [CrossRef]

17. Jorgenson, M.T.; Brown, J. Classification of the Alaskan Beaufort Sea Coast and estimation of carbon and sediment inputs from coastal erosion. Geo-Mar. Lett. 2005, 25, 69-80. [CrossRef]

18. Pedrazas, M.N.; Cardenas, M.B.; Demir, C.; Watson, J.A.; Connolly, C.T.; McClelland, J.W. Absence of ice-bonded permafrost beneath an Arctic lagoon revealed by electrical geophysics. Sci. Adv. 2020, 6, eabb5083. [CrossRef]

19. Western Regional Climate Center. Available online: https://wrcc.dri.edu/ (accessed on 18 February 2017).

20. Zhang, J.; Liu, F.; Tao, W.; Krieger, J.; Shulski, M.; Zhang, X. Mesoscale Climatology and Variation of Surface Winds over the Chukchi-Beaufort Coastal Areas. J. Clim. 2016, 29, 2721-2739. [CrossRef]

21. National Oceanic and Atmospheric Administration (NOAA). Tides and Currents-Prudhoe Bay, AK-Station ID 9497645 Available online: http:/ / tidesandcurrents.noaa.gov / stationhome.html?id=9497645 (accessed on 28 January 2020).

22. Reimnitz, E.; Maurer, D.K. Effects of Storm Surges on the Beaufort Sea Coast, Northern Alaska. Arctic 1979, 32, 329-344. [CrossRef]

23. Sultan, N.J.; Braun, K.W.; Thieman, D.S.; Sampath, A. North slope trends in sea level, storm frequency, duration and intensity. In Proceedings of the Ice Tech Conference, Anchorage, AK, USA, 20-23 September 2010; pp. 199-204.

24. Yin, J.H. A consistent poleward shift of the storm tracks in simulations of 21st century climate. Geophys. Res. Lett. 2005, 32, 1-4. [CrossRef]

25. Hume, J.D.; Schalk, M. Shoreline Processes near Barrow, Alaska: A Comparison of the Normal and the Catastrophic. Arctic 1967, 20, 86-103. [CrossRef]

26. Swail, V.R.; Cardone, V.J.; Callahan, B.; Ferguson, M.; Gummer, D.J.; Cox, A.T. The MSC Beaufort wind and wave reanalysis. In Proceedings of the 10th International Workshop on Wave Hindcasting and Forecasting and Coastal Hazard Symposium, North Shore, Oahu, HI, USA, 11-16 November 2007; p. 22.

27. Wiseman, J.W.J.; Coleman, J.M.; Gregory, A.; Hsu, S.-A.; Short, A.D.; Suhayda, J.N.; Waters, J.C.D.; Wright, L.D. Alaskan Arctic Coastal Processes and Morphology; Coastal Studies Institute Technical Report No. 149; Louisiana State University: Baton Rouge, LA, USA, 1973; p. 171.

28. Baranskaya, A.; Novikova, A.; Shabanova, N.; Belova, N.; Maznev, S.; Ogorodov, S.; Jones, B.M. The Role of Thermal Denudation in Erosion of Ice-Rich Permafrost Coasts in an Enclosed Bay (Gulf of Kruzenstern, Western Yamal, Russia). Front. Earth Sci. 2021, 8, 659. [CrossRef]

29. Gibbs, A.E.; Nolan, M.; Richmond, B.M.; Snyder, A.G.; Erikson, L.H. Assessing patterns of annual change to permafrost bluffs along the North Slope coast of Alaska using high-resolution imagery and elevation models. Geomorphology 2019, 336, $152-164$. [CrossRef]

30. Hoque, M.A.; Pollard, W.H. Arctic coastal retreat through block failure. Can. Geotech. J. 2009, 46, 1103-1115. [CrossRef] 
31. Thomas, M.A.; Mota, A.; Jones, B.M.; Choens, R.C.; Frederick, J.M.; Bull, D.L. Geometric and Material Variability Influences Stress States Relevant to Coastal Permafrost Bluff Failure. Front. Earth Sci. 2020, 8, 143. [CrossRef]

32. Brown, J.; Sellman, P.V. Permafrost and Coastal Plain History of Arctic Alaska; Technical Paper 25; Alaskan, A.T., Max, E.B., Eds.; Arctic Institute of North America: Washington, DC, USA, 1973; pp. 31-47.

33. Barnes, P.W.; Reimnitz, E.; Rollyson, B.P. Map Showing Beaufort Sea Coastal Erosion and Accretion between Flaxman Island and the Canadian Border, Northeastern Alaska: Thirty-Year Coastline Comparison, Sediment Volumes Released, and Physiographic Character; IMAP 1182H; U.S. Geological Survey: Reston, VA, USA, 1992.

34. Overduin, P.P.; Strzelecki, M.C.; Grigoriev, M.N.; Couture, N.; Lantuit, H.; St-Hilaire-Gravel, D.; Günther, F.; Wetterich, S. Coastal changes in the arctic. Geol. Soc. Spec. Publ. 2014, 388, 103-129. [CrossRef]

35. Reimnitz, E.; Graves, S.M.; Barnes, P.W. Beaufort Sea Coastal Erosion, Sediment Flux, Shoreline Evolution, and the Erosional Shelf Profile; IMAP 1182G; U.S. Geological Survey: Reston, VA, USA, 1988.

36. Wobus, C.; Anderson, R.; Overeem, I.; Matell, N.; Clow, G.; Urban, F. Thermal Erosion of a Permafrost Coastline: Improving Process-Based Models Using Time-Lapse Photography. Arct. Antarct. Alp. Res. 2011, 43, 474-484. [CrossRef]

37. Himmelstoss, E.A.; Henderson, R.E.; Kratzmann, M.G.; Farris, A.S. Digital Shoreline Analysis System (DSAS) Version 5.0 User Guide; Open-File Report 2018-1179; U.S. Geological Survey: Reston, VA, USA, 2018. [CrossRef]

38. Hapke, C.J.; Himmelstoss, E.A.; Kratzmann, M.G.; List, J.H.; Thieler, E.R. National Assessment of Shoreline Change; Historical Shoreline Change along the New England and Mid-Atlantic Coasts; Open-File Report 2010-1118; U.S. Geological Survey: Reston, VA, USA, 2011. [CrossRef]

39. Ruggerio, P.; Kratzmann, M.G.; Himmelstoss, E.A.; Reid, D.; Allan, J.; Kaminsky, G. National Assessment of Shoreline Change: Historical Shoreline Change along the Pacific Northwest Coast; Open-File Report 2012-1007; U.S. Geological Survey: Reston, VA, USA, 2013. [CrossRef]

40. Gibbs, A.E.; Jones, B.M.; Richmond, B.M. A GIS Compilation of Vector Shorelines and Coastal Bluff Edge Positions, and Associated Rate-of-Change Data for Barter Island, Alaska; U.S. Geological Survey: Reston, VA, USA, 2020. [CrossRef]

41. Reguero, B.G.; Losada, I.J.; Méndez, F.J. A global wave power resource and its seasonal, interannual and long-term variability. Appl. Energy 2015, 148, 366-380. [CrossRef]

42. Nippon Foundation-GEBCO Seabed 2030 Arctic and North Pacific Regional Center. Gridded Bathymetry Data for the Arctic Ocean Area (IBCAO) (gebco.net). Available online: https://www.gebco.net/data_and_products/gridded_bathymetry_data/ arctic_ocean (accessed on 4 June 2020).

43. Camus, P.; Mendez, F.J.; Medina, R. A hybrid efficient method to downscale wave climate to coastal areas. Coast. Eng. 2011, 58, 851-862. [CrossRef]

44. Irrgang, A.M.; Lantuit, H.; Manson, G.K.; Günther, F.; Grosse, G.; Overduin, P.P. Variability in Rates of Coastal Change Along the Yukon Coast, 1951 to 2015. J. Geophys. Res. 2018, 123, 779-800. [CrossRef]

45. Thomson, J.; Fan, Y.; Stammerjohn, S.; Stopa, J.; Rogers, W.E.; Girard-Ardhuin, F.; Ardhuin, F.; Shen, H.; Perrie, W.; Shen, H.; et al. Emerging trends in the sea state of the Beaufort and Chukchi seas. Ocean. Model. 2016, 105, 1-12. [CrossRef]

46. Barnhart, K.R.; Miller, C.R.; Overeem, I.; Kay, J.E. Mapping the future expansion of Arctic open water. Nat. Clim. Chang. 2016, 6, 280-285. [CrossRef]

47. Kupilik, M.; Ulmgren, M.; Brunswick, D. Bayesian Parameter Estimation for Arctic Coastal Erosion Under the Effects of Climate Change. IEEE J. Sel. Top. Appl. Earth Obs. Remote. Sens. 2020, 13, 3595-3604. [CrossRef] 